\title{
When Education Explains Strong Institutions: Trade Policy also Matters
}

\section{Dawood Mamoon}

University of Management and Technology

C-II, Johar Town, 54770

Lahore, Pakistan

dmamoon@gmail.com

\&

S Mansoob Murshed

Coventry University

William Morris Building, Gosford Street, Coventry CV1 5FB, UK

$\&$

International Institute of Social Studies (ISS), Erasmus University Rotterdam (EUR)

PO Box 29776

2502 LT, The Hague, The Netherlands

Murshed@iss.nl

\begin{abstract}
This paper empirically examines the contribution of trade liberalisation to differences in the level of prosperity across nations. We compare this with the relative contribution of institutional capacity to prosperity, as well as the role of human capital accumulation in that respect. We employ several concepts of institutional quality, trade policy and openness variables following various definitions prevalent in the literature. Unlike in the comparable study by Rodrik et al (2004) we have (a) included a role for human capital, (b) employed six institutional variables compared to one only in Rodrik et al (rule of law), (c) included trade policy variables, and not just openness indicators and (d) expanded the set of openness measures employed. We discover that opening up domestic markets to foreign competition by removing trade restrictions and barriers may promote economic performance. Furthermore, developing human capital is as important as superior institutional functioning for economic wellbeing. We find that openness counts for little per se in explaining income differences across countries. This is because it is an outcome and not a cause. Trade policies, and liberalisation, on the other hand, are not insignificant in explaining cross-country per-capita income variation. With regard to trade policies, export taxes are the most important in explaining cross-country per-capita income differences.
\end{abstract}

Keywords: Trade Policy, Institutional Quality, Per-Capita Income Differences across Countries 
In 1980s and early 1990s, many developing countries opened up their economies and became a more integral part of global finance and trade. There is a rich set of literature which already investigates income driven determinants and processes of economic development. The degree of international trade, which is viewed by many as engine of growth (Dollar and Kraay, 2002, 2003) is a good proxy for capturing the effect of globalisation on economic growth. Other fundamental determinants can be identified by rediscovering Adam Smith's insight that countries need solid institutions for markets to work. Institutions capture many legal, political, economic and social outcomes that are necessary for development of the economy. Secure and stable property rights form the basis for well functioning legal institutions (Acemoglu, Johnson and Robinson, 2004, for example). Representative political institutions allowing for the participation of minority groups can constitute institutions for conflict management. Sound fiscal and monetary institutional capacities are necessary for ensuring economic stability. Regulatory institutions which manage a successful market economy are also manifestations of good economic institutions. In summary, institutions of a well-functioning social contract legitimise the market economy through social stability and social cohesion.

This paper contributes to the debate over the relative role of institutions versus international trade integration (or policies) in determining relative levels of prosperity across countries. In this connection, some authors such as Rodrik, Subramanian and Trebbi (2004, henceforth Rodrik et al.) claim that institutions dominate all other factors in determining income differences across countries. This analysis, based on an extension of their framework, is somewhat sceptical of this assertion. In addition, following Glaeser et al. (2004a, 2004b), we examine the role of human capital accumulation in this process, finding some support for their view that human capital can be just as important as institutional quality in determining future relative prosperity, and may even lead to improved institutional functioning. With regard to international trade and its impact on economic well-being, it should be borne in mind that trade can increase or decrease independent of any changes to the trade policy stance (tariffs, non-tariff barriers, export subsidies etc.). ${ }^{1}$ Globalisation factors that are external to an individual nation, may facilitate trade. Technological changes may make certain goods, imports for example, cheaper despite the presence of trade restrictions. Similarly, a fall in transportation costs or the end of war may alter the relative price of tradables encouraging greater international trade. Trade may increase income, but changes in trade policies may not foster increased international trade and hence not contribute to growth or poverty reduction. In short, one has to distinguish between openness, something that is an outcome of policy choices or serendipity; and trade policies aimed at promoting greater international trade, which might or might not succeed. The following empirical work, unlike most authors, including Rodrik et al. (2004), draws this important distinction. We employ wide ranging definitions of institutions and economic openness. A rigorous statistical investigation is then carried out to do justice to the intellectual space which 'integration and institutions' have received recently.

The rest of the paper is organised as follows. Section 2 discusses the data and methodology, and section 3 (regression analysis) contains our contribution to the debate. The analysis, although similar to Rodrik et al. (2004), goes beyond their work by including more institutional measures, openness indicators, as well as explicit trade policy

\footnotetext{
1 Trade policy means, governmentally induced mechanisms that restrict, relax or facilitate the international exchange of certain or all goods and services.
} 
variables and a role for human capital. Therein lays the innovation of this paper. Finally, section 4 concludes.

$$
2 \quad \text { Data and Methodology }
$$

'Once institutions are controlled for trade is almost always insignificant, and often enters the income equation with the 'wrong (i.e.,) negative sign.' (Rodrik et al, 2004, 131) However, in another paper published in the same year, Rodrik (2004) writes 'I think the relationship is that the trade liberalization agenda today actually has become the elimination of (these) institutional differences (between developed and developing countries). '(p.517) The comparison of two contributions by the same author suggests that Rodrik et al (2004) finding regarding insignificance of trade in determining long term growth rates has been more of a case of an emphasis on statistical significance (insignificance) than on economic significance (insignificance)'. To infer that trade does not matter from Rodrik et al (2004) results would be invalid.

The economic significance of international trade and good institutions cannot be overemphasized. To be fair to Rodrik et al (2004), their findings need to be viewed in its right context. Rodriguez and Rodrik (2000) point out towards post 1980 promotion of international trade as a dominant determinant of economic growth such that other variables of interest had been largely ignored (for example see: Leamer, 1988; Dollar, 1992; Edwards, 1992; Sachs and Warner, 1995 and Frankel and Romer, 1999). In this context, the empirical exercise undertaken by Rodrik et al (2004) has rightly brought back the importance of institutions into economic policy making by finding the dominant role of 'rule of law' in explaining development or lack of it among developed and developing countries. The role of trade has only been underscored because of its statistical insignificance in the model. Such results can always be re-evaluated by using better empirical specifications. We extend their analysis and utilize some new datasets in a similar empirical frame work as Rodrik et al's (2004) to investigate the role of trade in relation to institutions and human capital.

Our empirical model includes many of the core determinants of growth at the right hand side, namely international economic integration (including measures of openness and trade policy), measures of institutional quality and human capital. On the left hand side, present dependent variable is not growth per se, but the log of income per-capita. As argued, differences in per-capita income across countries are a result of differential growth rates in the past. This model follows the practice in Easterly and Levine (2003) and Rodrik et al. (2004) where the relative contribution of policies and institutions in explaining per-capita income differentials is tested. This model's sample includes both rich OECD countries and developing countries. As regards policy, this paper examines the effect of both openness, as in Rodrik et al. (2004), as well as trade policy variables. Openness indicators are an outcome variable, pointing to the extent to which a country trades as a proportion of national income. Trade policy indicators are, however, a more direct measure of the policy stance, which Rodrik et al. (2004) did not examine. This paper deems these policy variables of greater significance in a test of the relative efficacy of policy vis-à-vis institutions. The final equation to estimate takes the following form:

$$
\log y_{i}=\alpha+\beta N_{i}+\chi T p_{i}+\gamma H k_{i}+G e o+\varepsilon_{i}
$$

The variable $y_{i}$ is income per capita in country i, $N_{i}, T p_{i}, H k_{i}$ and $G e o_{i}$ are respectively measures for institutions, international economic integration or trade policy, human 
capital, physical capital and geography, $\varepsilon_{i}$ is the random error term. Average years of schooling represent human capital. In order to have in-depth insight into how institutions or increased integration affects income per-capita, this paper employs several concepts of institutional quality, trade policy and openness variables following various definitions prevalent in the literature.

We employ two general estimation specifications for right-hand side variables. In specification 1, we have combined openness or trade policy indicators with institutions as well as human capital; and specification 2 corresponds to Rodrik et al. (2004) where trade policy or openness indicators are juxtaposed only against institutions. Table 1 provides summary statistics for all endogenous dependent, endogenous independent and independent measures and their respective definitions.

Table 1. Summary Statistics

\begin{tabular}{|c|c|c|c|c|}
\hline Variables & Code & Source & Obs & Std. Dev \\
\hline \multicolumn{5}{|l|}{ Dependent } \\
\hline \multicolumn{5}{|l|}{ Endogenous Independent } \\
\hline $\begin{array}{l}\text { (Exports Hmports)/ GDP at current Dollar prices, } \\
1985\end{array}$ & Lcopen & World Development Indicators & 170 & $(0.589)$ \\
\hline \multicolumn{5}{|l|}{ Trade Policy Variables } \\
\hline Import duties as \%imports, 1985 & Tariffs & World Development Indicators & 99 & $(8.903)$ \\
\hline $\begin{array}{l}\text { Tariffs on international inputs and capital goods, } \\
1985\end{array}$ & Owti & Sachs and Warner (1995) & 98 & $(0.165$ \\
\hline Trade taxes/ trade, 1982 & Txtrdg & Pritchett (1996) & 54 & $(0.031)$ \\
\hline Weighted average of total import charges, 1985 & Totimpov85 & $\begin{array}{l}\text { Pritchett (1996) } \\
\text { (Available for developing countries } \\
\text { only) }\end{array}$ & 76 & $(21.30)$ \\
\hline Non-tariff barriers Coverage: overall, 1987 & Ntarfov87 & $\begin{array}{l}\text { Pritchett (1996) } \\
\text { (Available for developing countries } \\
\text { only) }\end{array}$ & 76 & $(36.305)$ \\
\hline Sachs and Warners composite openness index, 1980 & Open80s & Edwards (1998) & 61 & $(0.446)$ \\
\hline $\begin{array}{l}\text { Leamer's measure of openness based on residuals } \\
\text { capturing deviations of actual trade from trade as } \\
\text { predicted by an empirical factor proportions model } \\
\text { of trade, } 1980\end{array}$ & Leamer82 & Edwards (1998) & 47 & $(0.527)$ \\
\hline \multicolumn{5}{|l|}{ Institutional Variables } \\
\hline Voice and Accountability, 1999 Range: 2.5 to -2.5 & $\mathrm{Va}$ & $\begin{array}{l}\text { Kaufmann, Kraay and Mastruzzi } \\
(2003)\end{array}$ & 170 & $(0.952)$ \\
\hline $\begin{array}{l}\text { Political stability, } 1999 \\
\text { Range: } 2.5 \text { to }-2.5\end{array}$ & Ps & $\begin{array}{l}\text { Kaufmann, Kraay and Mastruzzi } \\
(2003)\end{array}$ & 156 & $(0.954)$ \\
\hline \multicolumn{5}{|l|}{ Human Capital } \\
\hline Average years of Schooling, 1999 & Sch99 & Baro and Lee (2001) & 109 & $(2.914)$ \\
\hline \multicolumn{5}{|l|}{ Instruments } \\
\hline $\begin{array}{l}\text { Natural logarithm of predicted trade shares } \\
\text { computed from a bilateral trade equation with } \\
\text { 'pure geography' variables, } 1985\end{array}$ & Lfrkrom & Frankel and Romer (1999) & 163 & $(16.75)$ \\
\hline Fraction of the population speaking English & Engfrac & Hall and J ones (1999) & 182 & $(0.236)$ \\
\hline $\begin{array}{l}\text { Fraction of the population speaking one of the } \\
\text { major languages of Western Europe: French, } \\
\text { German, Portugese or Spanish }\end{array}$ & Eurfrac & Hall and J ones (1999) & 185 & $(0.380)$ \\
\hline Drop out rate, 1990 & Drop90 & Barro and Lee (1996) & 125 & $(0.802)$ \\
\hline Number of school days & Schday & Barro and Lee (1996) & 139 & $(23.43)$ \\
\hline $\begin{array}{l}\text { Distance from the equator of capital city measured } \\
\text { as abs (Latitude)/ } 90\end{array}$ & Disteq & $\begin{array}{l}\text { Acemoglu, J ohnson and Robinson (AJ R) } \\
(2001)\end{array}$ & 208 & $(16.65)$ \\
\hline
\end{tabular}




\subsection{Measuring Economic Growth:}

For most developing countries, growth rates have been highly volatile and unstable. In empirical studies, using growth rates as a measurement of development would also incorporate the volatility of growth rates in the analysis. Thus, per capita differences in income may be more suitable for an empirical exercise which sets out to determine the factors which lead to economic development. Income differences which prevail today among countries suggest that incomes in developing countries have failed to converge to that of higher income countries because of failing growth rates. An argument in favour of per capita income difference over GDP per capita growth rates does find some support in economic literature that has considered the econometric problems in using growth rates because of the enormous volatility of growth rates (Pritchett, 2000; 247)

\subsection{Measuring Institutions}

Kaufman et al (2003) have constructed six aggregate indicators of institutional quality: rule of law $(R)$, political stability $(P s)$, regulatory quality $(R q)$, government effectiveness $(G e)$, voice and accountability $(V a)$ and control of corruption $(C t c)$. The six governance indicators follow either of the 3 basic definitions of governance: (1) the process by which governments are selected, monitored and replaced (2) the capacity of the government to effectively formulate and implement sound policies, and (3) the respect of citizens and the state for the institutions that govern economic and social interactions among them. Kaufman et al (2003) relied on 194 different measures of governance drawn from 17 different sources of subjective governance data constructed by 15 different sources including international organizations, political and business risk rating agencies, think tanks and non-governmental organizations. The governance indicators have been oriented so that higher values correspond to better outcomes on a scale from -2.5 to 2.5 while covering these values for 175 countries.

The rule of law only partly defines governance, and by incorporating the other five measures of governance developed by Kaufman et al (2003), one can carry out a comprehensive institutional analysis. For example, voice and accountability has been constructed from number of indicators which measure different aspects of political process, civil liberties and political rights. In other words, voice and accountability measures the extent to which citizens of a country are able to participate in the selection of governments. Independence of media is also part of voice and accountability, whereas it may capture the monitoring role of the media through which they hold governments accountable for their actions. Political stability (Ps) is broadly defined to measure stability of government and absence of violence. It includes perceptions of the chances that the government in power will be destabilized or overthrown by unconstitutional and/or violent means from foreign or domestic forces of discontent or through terrorism. Government Effectiveness $(G e)$ and Regulatory Quality $(R q)$ captures the second dimension of governance which is to do with the ability of the government to formulate and implement sound policies. In other words it captures the quality of public service provision, the quality of the bureaucracy, the competence of civil servants, the independence of the civil service from political pressures and the credibility of the government's commitment to policies. The main focus of this index is on "inputs" required for the government to be able to produce and implement good policies and deliver public goods. (Kaufman et al, 2003: 3). Regulatory quality captures the incidence of market unfriendly policies which may include price controls, inadequate bank supervision and also perceptions of protection against foreign trade or excessive 
regulation against business development. One important point to note here is that these indicators are based on perceptions.

\subsection{Measuring Integration: (openness/ Trade Policy Variables)2}

The ratio of nominal imports plus exports to GDP (lcopen) is the conventional openness indicator (Frankel and Romer 1999; Alcala and Ciccone 2004; Rose 2002; Dollar and Kraay 2002; Rodrik et al. 2004). Cross country differences in trading volumes may not entirely reflect trade policy and level of integration of a country. Nevertheless, one may categorize the nominal openness measure as an outcome-based measure of trade policy which captures the deviation of actual outcome from what the outcome would have been without trade barriers.

In addition to nominal trade shares, there are two additional measures of integration introduced in trade literature which are outcome based: Pritchet (1996) estimates trade flows adjusted for country-characteristics. He has categorized it as an outcome based structure adjusted trade intensity measure which estimates trade penetration. The adjustment has been done by accounting for structural characteristics such as level of per capita GDP, size (both area and population), transport costs and obvious resource endowment characteristics. The adjusted trade penetration measures are obtained for total trade (exports plus imports) (Tarshov) and total imports (Impnov).

Neither of these measures are direct indicators of a country's trade policy, pointing only towards the level of its participation in international trade. There are many incidence based indicators of trade restrictiveness acting as close proxies of trade policy (Pritchett, 1996; Edwards 1998; Greenaway et al. 2001; Rose 2002). Despite some scepticism (Dollar and Kraay, 2004), empirical research has failed to come up with better alternates. According to Rodriguez and Rodrik (2000), simple averages of taxes on imports and exports and NTB coverage ratios have generally passed the rigours of empirical research and all such incidence based measures are considered to have done a decent job in rankordering countries according to the restrictiveness of their trade regimes.

Import tariffs as percentage of imports (Tariffs), tariffs on intermediate inputs and capital goods $(O w t i)$, trade taxes as a ratio of overall trade (Txtrg) and total import charges (Totimpov85) are all incidence-based measures of trade barriers and are considered good proxies for trade restrictiveness. All of the above are employed in this study. Other measures that capture restrictions in overall trade are non-tariff barriers. Here, the overall non-tariff coverage (Ntarfov87) and non- tariff barriers on intermediate inputs and capital goods $(O w q i)$ are the two proxies for non-tariff barriers.

There is also a trend in the trade literature to use composite measures of trade policy. Edwards (1998) advocates the Sachs and Warner (1995) openness index (Open80). The Sachs-Warner criteria defines a country as open if (1) non-tariff barriers cover less than 40 per cent of trade, (2) average tariff rates are less than 40 per cent, (3) the black market premium was less than 20 per cent during the 1980s, (4) the economy is not socialist, and (5) the government does not control major exports through marketing boards. The rationale for combining these indicators into a single dichotomous variable is that they represent different ways policymakers can close the economy to international trade. Another measure of trade barriers is based on residuals from trade equations and it is computed for the total trade for a country as the sum of deviations of the predicted from

\footnotetext{
${ }^{2}$ For detailed discussion on outcome based and incidence based measures of trade policy, see Rose (2002) and Pritchett (1996).
} 
the actual level of net exports across all available commodities. Pritchett (1996) calls it the endowment adjusted trade intensity ratio or simply Leamer's openness index (leamer82).

\subsection{Measuring Human Capital}

Although growth theory specifically focuses on the important role of human capital in form of education, the data on such an education measure which can easily be compared across countries has not been forthcoming until recently when Barro and Lee (1993) constructed a large data set on school attainments disaggregated by age, sex and level of schooling. They have also calculated average years of schooling which is a single comparable measure of school attainment that takes into account the significant variations across countries in the standard number of schooling at each level of attainment.

In this paper, we use average years of schooling for 1999 (Sch99). Earlier years of schooling from say 1960 or 1965 can be utilized to measure differences in initial human capital across countries in order to find out historic role of human capital in determining levels of incomes. Average years of schooling for 1960 or 1965 can be considered as initial level of human capital in a sense that levels of human capital in 1960s would be independent to policies in the economic reform period of 1980s and afterwards. In contrast to human capital formation in 1960s, later years of schooling especially post 1980s levels are interlinked with the reform period and would be as endogenous a concept as integration or economic growth is itself. Due to space constraints, this paper limits itself to average years of schooling for year 1999 as an endogenous variable. Nevertheless, suffice to say here that an intensive empirical exercise is also carried out where initial level of human capital is utilized in eq. 1 when it was considered exogenous. The results confirm that countries that have started out with low level of human capital have also lagged behind in incomes from countries that have started out with higher levels of human capital. The results are not presented or discussed here.

In summary, this study employs six institutional and 11 openness variables in an attempt to undertake a comprehensive analysis of how institutional quality and exposure to increased international trade affects the economic performance of a country. Unlike in the comparable study by Rodrik et al. (2004), this paper has (a) included a role for human capital, (b) employed six institutional variables compared to only one in Rodrik et al. (rule of law), (c) included trade policy variables and not just openness indicators, and (d) expanded the set of openness measures employed.

\subsection{Finding the Instruments}

There are potential endogeneity problems between per-capita income and institutions, per-capita income and human capital, as well as between openness (or the trade policy stance) and income per-capita. One way of cleansing the empirical analysis from endogeneity in explanatory variables and the reverse causality between dependent and independent variables is to adopt Instrumental Variable (IV) techniques in the context of two stage least squares regression analysis (2SLS). As a first step to run IV regressions, we need to find appropriate instruments for the 11 openness/trade policy variables, six institutional concepts and human capital. The first stage estimation includes instruments for the regressors with potential endogeneity problems. The regression estimate in the next stage utilizes the predicted values of these variables in a standard per-capita income or growth regression as in Eq. (1). 
Trade between nations may in most cases also capture their geographic proximity to each other in addition to other things. Frankel and Romer (FR) (1999) obtain predicted trade shares through a gravity equation. These are utilized to instrument outcome based measure of openness. (Rodrik et al, 2004). Traditionally, especially in 1980s, countries in the South, South East and East have been on average more protective than the countries that lie in the North, North West or West. Since all proxies of incidence based measures of trade barriers are for the period of 1980s, FR trade shares based on gravity equation may effectively explain trade policy in addition to openness.

A popular institutional instrument in the cross country growth literature has been the measure of settler mortality as suggested by Acemolgu, Johnson and Robinson (AJR) (2001). AJR argued that colonial settlements were directly proportional to the mortality rate of the settlers, whereas settlements affected early institutions which have persisted and formed current institutions. Recently, Rodrik et al (2004) has shown that AJR's settler mortality works very well to explain institutions. However, there are some serious drawbacks to this instrument. First, the data is only available for 64 countries. Rodrik et al. (2004) extended it to 80 countries; it still covers a relatively low numbers when compared to another widely used institutional instrument namely, 'fractions of the population speaking English' (Engfrac) and 'Western European languages as the first language' (Eurfrac), which covers as many as 140 countries. In addition to data limitation, settler mortality may be correlated with error terms in growth equations because of its strong relationship with human capital. According to Glaeser et al (2004a), it is not clear what Europeans really brought with them when they settled. It might be that what settlers brought with them was themselves and therefore their know-how and human capital. Here we follow Hall and Jones (1999), to use 'fractions of the population speaking English' (Engfrac) and 'Westem European languages as the first language' (Eurfrac) as instruments for the institutional proxies ( $V a, P s, \mathrm{Rl}, \mathrm{Ctc}, \mathrm{Rq}$ and $\mathrm{Ge}$ ), as arguably the most desirable institutions originate from that segment of Europe.

There are many qualitative and quantitative measures of education which can be potential instruments for average years of schooling $(S c h 99)$. Public spending on education, real public educational spending per pupil, teacher salary, pupil teacher ratio, availability of teaching material at different levels of education. Most of them have been available in Barro and Lee data sets and utilized in various studies (Barro and Lee, 2001; and 1996). Can they be instruments for average years of schooling? In growth framework, most of these qualitative and quantitative proxies of education are interlinked with incomes and thus would be correlated with error terms in equation 1. In contrast to these measures, proxies for student performance are relatively exogenous educational inputs capturing the element of student capability. Cross country data on test scores and drop out rates are available. The data on test scores for single common subject area is not comparable for larger set of countries (e.g. only mathematics sciences cover a maximum of 50 countries), whereas data on drop out rates are available for 125 countries.

Barro and Lee (2001) define drop out rates as the percentage of children who start primary school but do not eventually reach the final grade of primary school. The variable is constructed by using data on enrolments and repeaters. Though the drop out rates are much higher in developing countries then in the OECD countries, the pattern may well be attributable to difference of culture than that of economic development and thus any relationship of drop out rates with income would only be indirect. The over identification and endogeneity tests which will follow in next sections will confirm 
whether drop out rates are correlated with error terms or they exogenously determine average years of schooling to eventually determine differences in per capita incomes.

Table 2

Drop Out Rates

\begin{tabular}{lr|r}
\hline \multirow{2}{*}{ Country } & \multicolumn{2}{c}{ Drop out rate } \\
\cline { 2 - 3 } & 1990 & 1970 \\
\hline Finland & $0 \%$ & $0 \%$ \\
Norway & $0 \%$ & $0 \%$ \\
Sweden & $0 \%$ & $0 \%$ \\
Singapore & $0 \%$ & $6.3 \%$ \\
Egypt & $0 \%$ & $22.1 \%$ \\
Denmark & $1 \%$ & $3 \%$ \\
Israel & $1 \%$ & $1 \%$ \\
SriLanka & $3 \%$ & $6 \%$ \\
Uruguay & $7 \%$ & $14 \%$ \\
Tonga & $8 \%$ & $8 \%$ \\
United States & $11 \%$ & $11 \%$ \\
China & $15 \%$ & $15 \%$ \\
Belgium & $19 \%$ & $22 \%$ \\
Zambia & $16 \%$ & $24 \%$ \\
Uganda & $24.3 \%$ & $22.4 \%$ \\
Argentina & $34.3 \%$ & $76 \%$ \\
Bangladesh & $53 \%$ & $78 \%$ \\
Brazil & $80 \%$ & $22 \%$ \\
Afghanistan & $72 \%$ & \\
\hline
\end{tabular}

Table 2 presents drop out rates for select number of developed and developing countries for the periods of 1990 and 1970. It is interesting to note that trends in drop out rates are quite independent to differences in incomes. Egypt and Sri Lanka fare better than the United States. China, despite its robust economic growth trends showed no improvement in drop out rates between 1970 and 1990. Belgium scored as low as Zambia and Uganda. Brazil and Argentina are affluent Latin American countries with high drop out rates compared to Uruguay. For Brazil, the drop out rate is slightly higher than that of present day war trodden Afghanistan. Considering these cross country patterns, one can safely suggest that drop out rates (Drop90) would not be related with the error terms in equation 2.1 and are exogenously determined in our framework. Another instrument which may exogenously explain $S \operatorname{ch99}$ is number of school days in a year $(S c h d a y)$ and has been utilized here.

Finally as in Hall and Jones (1999) and Rodrik et al (2004), we employ 'distance from the equator' as a fifth instrument (proxy for geography). This is a purely exogenous concept. The IV regression model has three equations, where in the first stage predicted values of institutions, openness/ trade policy and human capital are generated respectively by regressing them on 5 instruments.

$$
\begin{aligned}
& N_{i}=\lambda_{1 i}+\phi_{1} \text { Engfrac }_{i}+v_{1} \text { Eurfrac }_{i}+\tau_{1} F R_{i}
\end{aligned}
$$

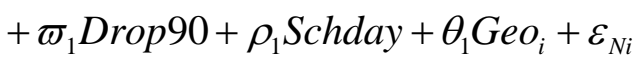

$$
\begin{aligned}
& \text { Tp }=\lambda_{21 i}+\phi_{2} \text { Engfrac }_{i}+v_{2} \text { Eurfrac }_{i}+\tau_{2} F R_{i} \\
& +\varpi_{2} \text { Drop } 90+\rho_{2} \text { Schday }+\theta_{2} \mathrm{Geo}_{i}+\varepsilon_{\mathrm{Ni}}
\end{aligned}
$$


$H k=\lambda_{3 i}+\phi_{3}$ Engfrac $_{i}+v_{3}$ Eurfrac $_{i}+\tau_{3} F R_{i}$

$+\varpi_{3}$ Drop $90+\rho_{3}$ Schday $+\theta_{3}$ Geo $_{i}+\varepsilon_{N i}$

Where as Engfrac ${ }_{i}$ and Eurfrac $_{i}$ are instruments for institutions referring to fractions of population speaking English and European languages respectively. $F R_{i}$ is instrument for trade policy. Drop90 ${ }_{i}$ is annual drop rate for 1990 and Schday $_{i}$ is number of school days in a year. $G_{e} o_{i}$ is proxy for geography showing distance from the equator. At the second stage, the predicted values of respective institutional, openness/ trade policy variables and human capital are in the per-capita income Eq. (1).

\section{REgRESSION RESULTS}

\subsection{Tests for the Relevance and Validity of Instruments}

Table. 3 First stage regression results for instrumental variables

\begin{tabular}{|c|c|c|c|c|c|c|c|c|c|}
\hline \multicolumn{10}{|c|}{ First Stage Results } \\
\hline & $\begin{array}{l}\text { Nominal } \\
\text { Trade share } \\
\text { (Icopen) }\end{array}$ & $\begin{array}{c}\text { Import } \\
\text { penetrations } \\
1985 \\
\text { (Impnov85) }\end{array}$ & $\begin{array}{c}\text { TARS trade } \\
\text { penetration } \\
1985 \\
\text { (Tarshov85) }\end{array}$ & $\begin{array}{l}\text { Import } \\
\text { duties as \% } \\
\text { Imports } \\
\text { (Tariffs) }\end{array}$ & $\begin{array}{l}\text { Tariffs on } \\
\text { international } \\
\text { inputs and } \\
\text { capital } \\
\text { goods (Owti) }\end{array}$ & $\begin{array}{l}\text { Trade taxes } \\
\text { (Txtrdg) }\end{array}$ & $\begin{array}{l}\text { Weighted } \\
\text { average of } \\
\text { total import } \\
\text { charges } \\
1985 \\
\text { (Totimpov85) }\end{array}$ & $\begin{array}{l}\text { Non trade } \\
\text { barriers } \\
\text { (Owqi) }\end{array}$ & $\begin{array}{c}\text { Non tariff } \\
\text { barriers } 1987 \\
\text { (Ntarov87) }\end{array}$ \\
\hline Lfrkrom & $\begin{array}{c}0.586 \\
(10.92)^{* 1+k}\end{array}$ & $\begin{array}{c}0.589 \\
(8.43)^{\text {*** }}\end{array}$ & $\begin{array}{c}0.512 \\
(8.03)^{* 1+k}\end{array}$ & $\begin{array}{l}-1.919 \\
(-1.38)\end{array}$ & $\begin{array}{l}-0.085 \\
(-1.85)^{*}\end{array}$ & $\begin{array}{l}0.006 \\
(1.48)\end{array}$ & $\begin{array}{l}-15.86 \\
(-2.44)^{\text {** }}\end{array}$ & $\begin{array}{l}-0.0313 \\
(-0.74)\end{array}$ & $\begin{array}{c}-13.07 \\
(-2.29)^{\text {*** }}\end{array}$ \\
\hline Engfrac & $\begin{array}{c}0.41 \\
(1.99)^{\text {** }}\end{array}$ & $\begin{array}{c}0.558 \\
(2.18)^{* * *}\end{array}$ & $\begin{array}{l}0.266 \\
(1.44)\end{array}$ & $\begin{array}{l}-3.14 \\
(-0.64)\end{array}$ & $\begin{array}{l}0.028 \\
(0.37)\end{array}$ & $\begin{array}{l}0.021 \\
(1.45)\end{array}$ & $\begin{array}{l}17.26 \\
(1.03)\end{array}$ & $\begin{array}{l}-0.067 \\
(-0.13)\end{array}$ & $\begin{array}{c}48.98 \\
(1.76)^{*}\end{array}$ \\
\hline Eurfrac & $\begin{array}{l}-0.061 \\
(-0.51)\end{array}$ & $\begin{array}{l}-0.143 \\
(-0.85)\end{array}$ & $\begin{array}{l}0.074 \\
(0.49)\end{array}$ & $\begin{array}{c}-4.80 \\
(-1.64)^{*}\end{array}$ & $\begin{array}{l}-0.098 \\
(-1.6)^{*}\end{array}$ & $\begin{array}{l}-0.028 \\
(-2.28)^{* *}\end{array}$ & $\begin{array}{l}-11.08) \\
(-1.03)\end{array}$ & $\begin{array}{l}-0.011 \\
(-0.13)\end{array}$ & $\begin{array}{l}-42.80 \\
(-3.7)^{* * *}\end{array}$ \\
\hline Drop90 & $\begin{array}{c}-0.006 \\
(-2.64)^{* * *}\end{array}$ & $\begin{array}{c}-0.006 \\
(-2.06)^{* *}\end{array}$ & $\begin{array}{c}-0.009 \\
(-3.4)^{* * *}\end{array}$ & $\begin{array}{l}0.075 \\
(1.21)\end{array}$ & $\begin{array}{c}0.001 \\
(1.65)^{*}\end{array}$ & $\begin{array}{l}0.0005 \\
(1.67)^{*}\end{array}$ & $\begin{array}{c}0.284 \\
(2.00)^{* *}\end{array}$ & $\begin{array}{l}0.001 \\
(0.73)\end{array}$ & $\begin{array}{l}0.378 \\
(1.54)\end{array}$ \\
\hline Schday & $\begin{array}{l}-0.002 \\
(-0.96)\end{array}$ & $\begin{array}{l}0.002 \\
(0.78)\end{array}$ & $\begin{array}{l}-0.001 \\
(-0.23)\end{array}$ & $\begin{array}{l}0.037 \\
(0.45)\end{array}$ & $\begin{array}{l}0.001 \\
(0.13)\end{array}$ & $\begin{array}{l}0.001 \\
(0.05)\end{array}$ & $\begin{array}{l}-0.062 \\
(-0.38)\end{array}$ & $\begin{array}{l}0.0009 \\
(0.63)\end{array}$ & $\begin{array}{l}0.084 \\
(0.28)\end{array}$ \\
\hline Disteq & $\begin{array}{c}-0.008 \\
(-2.89)^{* * *}\end{array}$ & $\begin{array}{l}0.001 \\
(0.00)\end{array}$ & $\begin{array}{c}-0.0028 \\
(-0.84)\end{array}$ & $\begin{array}{c}-0.129 \\
(-1.87)^{*}\end{array}$ & $\begin{array}{l}-0.001 \\
(-1.29)\end{array}$ & $\begin{array}{c}-0.0004 \\
(-1.35)\end{array}$ & $\begin{array}{l}0.259 \\
(1.15)\end{array}$ & $\begin{array}{l}-0.001 \\
(-0.10)\end{array}$ & $\begin{array}{l}0.022 \\
(0.05)\end{array}$ \\
\hline $\mathrm{N}$ & 87 & 72 & 72 & 70 & 70 & 45 & 51 & 69 & 51 \\
\hline $\mathrm{F}$ & 24.96 *** & $16.12^{* * *}$ & $15.20 *$ & $5.95^{* * *}$ & $4.66^{\text {**** }}$ & $5.45^{* * *}$ & $2.11 *$ & 0.96 & $3.61^{* *}$ \\
\hline R2 & 0.65 & 0.598 & 0.583 & 0.24 & 0.25 & 0.37 & 0.31 & 0.04 & 0.20 \\
\hline \multicolumn{10}{|c|}{ First Stage Results } \\
\hline & $\begin{array}{l}\text { Sachs and } \\
\text { Warner } \\
\text { openness } \\
1980 \\
\text { (Open80s) } \\
\end{array}$ & $\begin{array}{c}\text { Leamers } \\
\text { openness } \\
1980 \\
\text { (Leamer80s) }\end{array}$ & $\begin{array}{l}\text { Voice and } \\
\text { Accountabili } \\
\text { ty (Va) }\end{array}$ & $\begin{array}{l}\text { Political } \\
\text { Stability } \\
\text { (Ps) }\end{array}$ & $\begin{array}{c}\text { Government } \\
\text { Effectivenes } \\
\mathrm{s}(\mathrm{Ge})\end{array}$ & $\begin{array}{l}\text { Regulatory } \\
\text { Quality (Rq) }\end{array}$ & $\begin{array}{l}\text { Rule of law } \\
\text { (RI) }\end{array}$ & $\begin{array}{l}\text { Control for } \\
\text { Corruption } \\
\quad \text { (Ctc) }\end{array}$ & $\begin{array}{c}\text { Average } \\
\text { Years of } \\
\text { Schooling } \\
1999 \\
\text { (Sch99) } \\
\end{array}$ \\
\hline Lfrkrom & $\begin{array}{l}0.171 \\
(2.10)^{\text {** }}\end{array}$ & $\begin{array}{l}-0.102 \\
(-1.34)\end{array}$ & $\begin{array}{l}0.198 \\
(1.85)^{*}\end{array}$ & $\begin{array}{l}0.126 \\
(1.39)\end{array}$ & $\begin{array}{l}0.155 \\
(1.92)^{* *}\end{array}$ & $\begin{array}{l}0.043 \\
(0.72)\end{array}$ & $\begin{array}{l}0.157 \\
(2.01)^{* *}\end{array}$ & $\begin{array}{l}0.229 \\
(2.66)^{* * *}\end{array}$ & $\begin{array}{l}-0.026 \\
(-0.12)\end{array}$ \\
\hline Engfrac & $\begin{array}{l}-0.098 \\
(-0.30)\end{array}$ & $\begin{array}{l}-0.005 \\
(-0.02)\end{array}$ & $\begin{array}{l}0.324 \\
(1.59)\end{array}$ & $\begin{array}{l}-0.024 \\
(-0.09)\end{array}$ & $\begin{array}{l}0.034 \\
(0.11)\end{array}$ & $\begin{array}{l}-0.136 \\
(-0.86)\end{array}$ & $\begin{array}{l}-0.035 \\
(-0.10)\end{array}$ & $\begin{array}{l}0.479 \\
(1.57)\end{array}$ & $\begin{array}{l}0.502 \\
(0.56)\end{array}$ \\
\hline Eurfrac & $\begin{array}{l}0.156 \\
(0.89)\end{array}$ & $\begin{array}{l}-0.134 \\
(-0.80)\end{array}$ & $\begin{array}{l}0.888 \\
(5.04)^{* * * k}\end{array}$ & $\begin{array}{l}0.701 \\
(3.84)^{* * *}\end{array}$ & $\begin{array}{l}0.666 \\
(4.37)^{* * *}\end{array}$ & $\begin{array}{l}0.835 \\
(5.93)^{\text {*k* }}\end{array}$ & $\begin{array}{l}0.578 \\
(3.60)^{*}\end{array}$ & $\begin{array}{l}0.478 \\
(3.16)^{\text {*** }}\end{array}$ & $\begin{array}{l}2.341 \\
(4.62)^{* * *}\end{array}$ \\
\hline Drop90 & $\begin{array}{l}-0.001 \\
(-0.04)\end{array}$ & $\begin{array}{l}-0.005 \\
(-1.34)\end{array}$ & $\begin{array}{l}-0.009 \\
\left(-2.80^{*} * *\right.\end{array}$ & $\begin{array}{l}-0.013 \\
(-3.4)^{* * *}\end{array}$ & $\begin{array}{l}-0.015 \\
(-3.8)^{* * *}\end{array}$ & $\begin{array}{l}-0.01 \\
(-2.9)^{* * *}\end{array}$ & $\begin{array}{l}-0.019 \\
(-4.9)^{\text {*** }}\end{array}$ & $\begin{array}{l}-0.013 \\
(3.67)^{* * *}\end{array}$ & $\begin{array}{l}-0.053 \\
(-5.2)^{* * *}\end{array}$ \\
\hline Schday & $\begin{array}{l}-0.0002 \\
(-0.06)\end{array}$ & $\begin{array}{l}-0.001 \\
(-0.39)\end{array}$ & $\begin{array}{l}-0.004 \\
(-0.38)\end{array}$ & $\begin{array}{l}0.001 \\
(0.45)\end{array}$ & $\begin{array}{l}0.003 \\
(0.71)\end{array}$ & $\begin{array}{l}-0.003 \\
(-0.77)\end{array}$ & $\begin{array}{l}0.001 \\
(0.43)\end{array}$ & $\begin{array}{l}0.004 \\
(0.92)\end{array}$ & $\begin{array}{l}0.01 \\
(0.94)\end{array}$ \\
\hline Disteq & $\begin{array}{l}0.008 \\
(1.99)^{*}\end{array}$ & $\begin{array}{l}0.009 \\
(2.04)^{\text {** }}\end{array}$ & $\begin{array}{l}0.024 \\
(5.12)^{\text {*1kk }}\end{array}$ & $\begin{array}{l}0.026 \\
(4.89)^{\text {*** }}\end{array}$ & $\begin{array}{l}0.022 \\
(4.05)^{* * *}\end{array}$ & $\begin{array}{l}0.009 \\
(2.58)^{\text {*1kk }}\end{array}$ & $\begin{array}{l}0.024 \\
(5.06)^{* * *}\end{array}$ & $\begin{array}{l}0.027 \\
(5.06)^{* * *}\end{array}$ & $\begin{array}{l}0.081 \\
(5.78)^{* * *}\end{array}$ \\
\hline $\mathrm{N}$ & 48 & 41 & 88 & 84 & 85 & 87 & 87 & 86 & 87 \\
\hline $\mathrm{F}$ & $2.16^{* *}$ & $3.36 * *$ & $31.76^{* * *}$ & $27.64 * * *$ & $25.42^{* * *}$ & $17.21^{* 1 *}$ & $37.53^{* * *}$ & $26.54 *$ & $32.48^{*}$ \\
\hline R2 & 0.22 & 0.42 & 0.56 & 0.52 & 0.57 & 0.45 & 0.66 & 0.62 & 0.65 \\
\hline
\end{tabular}

In order to determine whether the 2SLS (2 stage least square) technique would provide better results than simple OLS (ordinary least square technique), the instruments should 
be correlated with the endogenous independent variable to explain variation such that the later is not correlated with error term. In other words, a good instrument, even if it is weakly related with its endogenous independent variables, should pass the relevance and endogeneity tests to begin with. 2SLS for equation (1) has been run on 2 broad specifications: (1) Openness or trade policy + Institutions + Human Capital, and (2) openness or trade policy + Institutions. As part of the 2SLS analysis, first stage regressions are run.

Table 3 suggests that the respective instruments carry the right signs for the proxies of integration and institutions. In some cases when the instruments carry the wrong signs, they are also insignificant. The $(F R)$ instrument is statistically significant for all openness variables and four out of six trade policy variables. Although $(F R)$ is not significant for all trade-policy variables, there is a strong one-to-one correlation between trade policy and $(F R)$ instrument and it enters the trade policy equation with a right sign. Similarly, ENG and EUR come out as sound instruments for institutions, and generally they have been significant and always with a right sign. Similarly, Drop90 and Schday establish themselves as good instruments. Drop out rates decrease institutional quality and countries with high drop out rates also trade less with rest of the world. Results show that countries with higher drop out rates would have greater levels of protection towards outside competition and average years of schooling decrease with increase in drop out rates. Schday is generally insignificant as well as Disteq but they remain important instruments because first stage regressions which employ all instruments give higher values of R2.

According to the Staiger and Stock (1997) rule of thumb, instrument is good if F-test for first stage regressions is equal to or greater than 10. Table 3 shows that for outcome based measures of trade barriers (openness), institutions and human capital F-statistic is much higher than 10, while for incidence based measures of trade barriers (trade policy), F-statistic is always less than 10. This may suggest that the instruments do work well in former case but the same instruments do not work well to explain trade policy and at best are weak. However, one may note here that Staiger and Stock rule of thumb is a good way to determine the validity of instruments when there is only one instrument and one endogenous independent variable. Stock and Yogo (2002) suggest that when the number of instruments is moderate or large as in our case, the first stage F-statistic does not provide substantial assurance that size distortion for (more than one) instrument in the model is controlled for. The size distortion is evidently present in first stage results as one can see from table 3. For many trade policy variables, most instruments actually work well even if the main instrument is weak (e.g. Lfrkrom). More importantly, relying completely on F-test statistics for first stage may lead to spurious inferences regarding the power of instruments because instruments may also be sensitive to other parameters and factors in the equation such as the very degree of endogeniety of the explanatory variables (Cruz and Moreira, 2005).

Since it quite difficult to find instruments especially in cross sections analysis which are exogenous and also relevant, weak instruments have been a great cause of interest in literature and many strategies to cope with the problem of weak instruments have been proposed which suggest a use of higher order asymptotic test techniques (Staiger and Stock, 1997; Hahn and Hausman, 2002; Cruz and Moreira, 2005). The Cragg-Donald (1993) type higher order asymptotic tests can be undertaken where endogenous independent variables are expected to exogenously determine the dependent variable. For such regressions, 2SLS bias should be small and lie under the Cragg-Donald critical values to establish the validity of IV. To test for exogeniety of instruments, over identification test is needed. The presence of over identification may indicate towards endogeniety which can be either directly running from instruments to the error term or it 
can be running from the variables which have been instrumented for to the error term. In both cases, with the presence of endogeniety in the estimation of the model, the purpose of utilizing instrumental variable technique would fail and simple OLS would become a preferred regression model. Another statistical issue which has to be addressed simultaneously is that of heteroskedasticity (Baum, Schaffer and Stillman, 2003).

In table 4, multiple tests are carried out to determine the relevance and exogeniety of instruments. Second order asymptotic analysis undertaken by Staiger and Stock (1997) reveal that Cragg and Donald (1993) type higher order asymptotic testing was necessary to establish the statistical validity of instruments. Cargg Donald statistical tests show that all but equations 2, 3, 6, 8 and 14, have passed the 2SLS minimal bias criterion and are significantly different than OLS. Largely instruments pass the relevance criterion. Overidentification test reveals that for equations $1,5,7,8,10,11$ and 14 the instruments are not exogenous to the error terms. One commonality which can be found in these results is that endogeniety is generally found between instruments and error terms, when rule of law (R) has entered into the equation with the combination of openness proxies and human capital (Sch99). Quite interestingly, IV analysis by Rodrik at al (2004, p 143) with $\mathrm{R} l$ and $L$ copen also failed to pass several over-identification tests:

Table 4. Multiple Tests for the Relevance and Quality of Instruments for $\operatorname{Ln} Y$

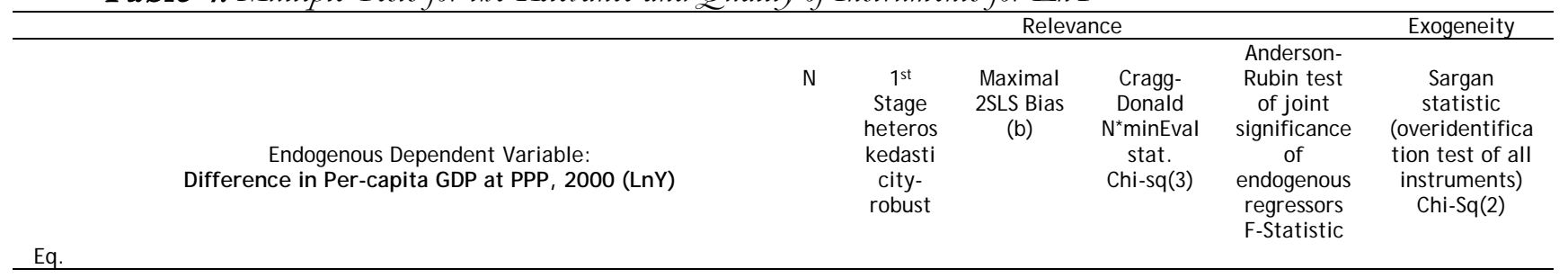

Endogenous Independent Variables : Openness, Institutions, Human Capital (Instruments= Disteq, Lfrkrom, Engfrac, Eurfrac)

\begin{tabular}{|c|c|c|c|c|c|c|c|}
\hline 1 & $\begin{array}{c}\text { Nominal Trade Shares, Voice and Accountability, Average Years of } \\
\text { Schooling, } 1999 \text { ( Lcopen, Va, Sch99) }\end{array}$ & 88 & Robust & 0.009 & $11.58^{* *}$ & $20.12^{\text {*** }}$ & $\begin{array}{l}8.146^{* * k} \\
(0.017)\end{array}$ \\
\hline 2 & $\begin{array}{c}\text { Nominal Trade Shares, Political Stability, Average Years of } \\
\text { Schooling, } 1999 \text { ( Lcopen, Ps, Sch99) }\end{array}$ & 84 & Robust & 0.74 & 1.23 & $18.48^{\text {*** }}$ & $\begin{array}{l}0.129 \\
(0.93)\end{array}$ \\
\hline 3 & $\begin{array}{c}\text { Nominal Trade Shares, Government Effectiveness, Average Years } \\
\text { of Schooling, } 1999 \text { (Lcopen, Ge, Sch99) }\end{array}$ & 85 & Robust & 0.88 & 0.64 & $18.84^{* * *}$ & $\begin{array}{l}0.149 \\
(0.92)\end{array}$ \\
\hline 4 & $\begin{array}{c}\text { Nominal Trade Shares, Regulatory Quality, Average Years of } \\
\text { Schooling, } 1999 \text { (Lcopen, Rg, Sch99) }\end{array}$ & 87 & Robust & 0.013 & $10.63^{* *}$ & $19.81^{\text {*** }}$ & $\begin{array}{l}2.85 \\
(0.24)\end{array}$ \\
\hline 5 & $\begin{array}{c}\text { Nominal Trade Shares, Rule of Law, Average Years of Schooling, } \\
1999 \text { (Lcopen, RI, Sch199) }\end{array}$ & 87 & Robust & 0.39 & $2.99 * *$ & $19.81^{\text {*** }}$ & $\begin{array}{l}13.37^{* * * k} \\
(0.001)\end{array}$ \\
\hline 6 & $\begin{array}{c}\text { Nominal Trade Shares, Control for Corruption, Average Years of } \\
\text { Schooling, } 1999 \text { (Lcpopen, Ctc, Sch99) }\end{array}$ & 86 & Robust & 0.81 & 0.97 & $19.35^{\text {*** }}$ & $\begin{array}{c}0.24 \\
(0.88)\end{array}$ \\
\hline 7 & $\begin{array}{c}\text { Import Penetration, 1985, Rule of Law, Average Years of } \\
\text { Schooling, } 1999 \text { (Impnov85, RI, Sch99) }\end{array}$ & 72 & Robust & 0.34 & $3.29 * *$ & $14.07^{* * *}$ & $\begin{array}{l}9.91^{* 1 * *} \\
(0.007)\end{array}$ \\
\hline 8 & $\begin{array}{c}\text { TARS trade Penetration, 1985, Rule of Law, Average Years of } \\
\text { Schooling, } 1999 \text { (Tarshov85, RI, Sch99) }\end{array}$ & 72 & Robust & 0.51 & $2.31 * *$ & $14.07^{* * *}$ & $\begin{array}{l}11.29 * 1 * \\
(0.003)\end{array}$ \\
\hline
\end{tabular}

Endogenous Independent Variables: Trade Policy, Institutions, Human Capital (Instruments= Disteq, Lfrkrom, Engfrac, Eurfrac, Dr op90, Schday)

\begin{tabular}{|c|c|c|c|c|c|c|c|}
\hline 9 & $\begin{array}{c}\text { Import duties, Rule of Law, Average Years of Schooling, } 1999 \\
\text { (Tariff, RI, Sch99) }\end{array}$ & 70 & Robust & 0.28 & $3.77^{* *}$ & $13.20^{* * *}$ & $\begin{array}{l}5.91^{* * *} \\
(0.05)\end{array}$ \\
\hline 10 & $\begin{array}{c}\text { Tariffs on International Inputs and Capital Goods, Rule of Law, } \\
\text { Average Years of Schooling, } 1999 \\
\text { (Owti, RI, Sch99) }\end{array}$ & 70 & Robust & 0.29 & $3.68 * *$ & $16.09 * * *$ & $\begin{array}{l}6.98^{* * *} \\
(0.03)\end{array}$ \\
\hline 11 & $\begin{array}{c}\text { Trade Taxes, Rule of Law, Average Years of Schooling, } 1999 \\
\text { (Txtrdg, RI, Sch99) }\end{array}$ & 45 & Robust & 0.18 & $4.88 * *$ & $8.65^{* * k}$ & $\begin{array}{c}2.07 \\
(0.35)\end{array}$ \\
\hline 12 & $\begin{array}{c}\text { Weighted Average of Total import Charges, 1985, Rule of Law, } \\
\text { Average Years of Schooling, 1999 } \\
\text { (Totimpov85, Rl, Sch99) }\end{array}$ & 52 & Robust & 0.019 & $9.91^{* *}$ & $5.55^{* * *}$ & 4.602 \\
\hline 13 & $\begin{array}{c}\text { Non Trade Barriers, Rule of Law, Average Years of Schooling, } \\
1999 \text { (Owqi, RI, Sch99) }\end{array}$ & 69 & Robust & 0.84 & 0.84 & $15.54^{* * *}$ & $\begin{array}{l}7.86^{* * *} \\
(0.01)\end{array}$ \\
\hline 14 & $\begin{array}{c}\text { Non Tariff Coverage, 1987, Rule of Law, Average Years of } \\
\text { Schooling, } 1999 \text { (Ntarfov87, R, Sch99) }\end{array}$ & 51 & Robust & 0.13 & $5.55^{\text {** }}$ & $9.92^{* * *}$ & $\begin{array}{l}3.73 \\
(0.15)\end{array}$ \\
\hline 15 & $\begin{array}{c}\text { Sachs and Warner Openness, 1980, Rule of Law, Average Years of } \\
\text { Schooling, } 1999 \text { (Open80s, Rl, Sch99) }\end{array}$ & 48 & Robust & 0.19 & $4.69 * *$ & $14.17^{\text {*** }}$ & $\begin{array}{l}3.15 \\
(0.20)\end{array}$ \\
\hline 16 & $\begin{array}{c}\text { Leamers Openness, 1980; Rule of Law, Average Years of } \\
\text { Schooling, 1999 (Leamer82, RI, Sch99) }\end{array}$ & 41 & Robust & 0.23 & $4.29 * *$ & $5.66^{* * *}$ & $\begin{array}{c}2.39 \\
(0.30)\end{array}$ \\
\hline
\end{tabular}


We find that our IV analysis mostly passes over identification tests for trade policy, if not openness. 2SLS Bias obtained from Cragg-Donald critical values also pass the relevance test of instruments for trade policy. This is interesting result in comparison to the first stage F-statistics provided in table (3), where F-statistics were higher for Openness variables passing Staiger and Stock rule of thumb; while all trade policy variables failed this criterion. Our results complement the assertion of Stock and Yogo (2004) and Cruz and Moreira (2005) that a higher order asymptotic test is necessary to ensure the statistical validity of weak instruments and Staiger and Stock rule of thumb may result in misleading statistical inference where instruments are large or moderate in number. Despite low values of F-statistic for trade policy proxies in the first stage, instruments explain them well by passing higher order asymptotic tests for relevance and exogeneity.

\subsection{Similarities between Our OLS and Rodrik et al.'s (2004) IV Analysis}

Results in table 4 also show that there are some instances of a presence of high 2SLS bias in favour of OLS, especially in case of such specifications where openness instead of trade policy enters into equation (1). OLS results are obtained for equation 1 for specification 1, where human capital is present in addition to institutional and openness/ trade policy proxies. (Table 5) The results present an interesting picture in light of Rodrik et al (2004). For all cases, whenever openness enters into the equation (1), it is insignificant. This is a similar result to Rodrik et al (2004), when they instrumented rule of law with settler mortality rate. They also find that openness variable has entered the equation mostly insignificantly. Table 5 reveals a similar pattern in our OLS analysis.

If their IV estimates suffer from the problem of endogeniety as suggested by Glaeser et al (2004a), then our OLS analysis and Rodrik et al's IV analysis have given similar results for institutions and openness because settler mortality is closely related with the human capital that the settlers brought to the settlements. According to Glaeser et al (2004a), settler mortality actually explains human capital formation in the settlements instead of institutions. If that is indeed the case, it is the effect of human capital formation which has been driving the results on institutions for Rodrik et al (2004). In this respect, our OLS regressions correspond to their IV. If settler mortality increases the significance of institutions and causes openness to lose its significance in Rodrik et al (2004), Sch99 has done the same in our OLS estimates. The correlation between settler mortality (a proxy for human capital), rule of law and income differences would capture a similar effect in IV than if a linear relationship is sought between Sch99 (proxy of human capital), rule of law (or other institutional outcome) and income difference under an OLS.

Table 5 indicates that import duties (Tariffs), tariffs $(O w t i)$, trade taxes (Txtrdg) and NTBs (Ntarfov87) are significantly and negatively related with income differences. A higher coefficient of Txtrdg means that more integration with rest of the world through decrease in trade taxes (i.e., export taxes) is at least as relevant as developed human capital or strong institutions. However, only in coming lines the statistical validity can really be established when results based on IV analysis are discussed and similar comparisons between openness/trade policy, institutions and human capital are drawn. 
Table 5. OLS Results for Openness/ Trade Policy, Institutions and Human Capital

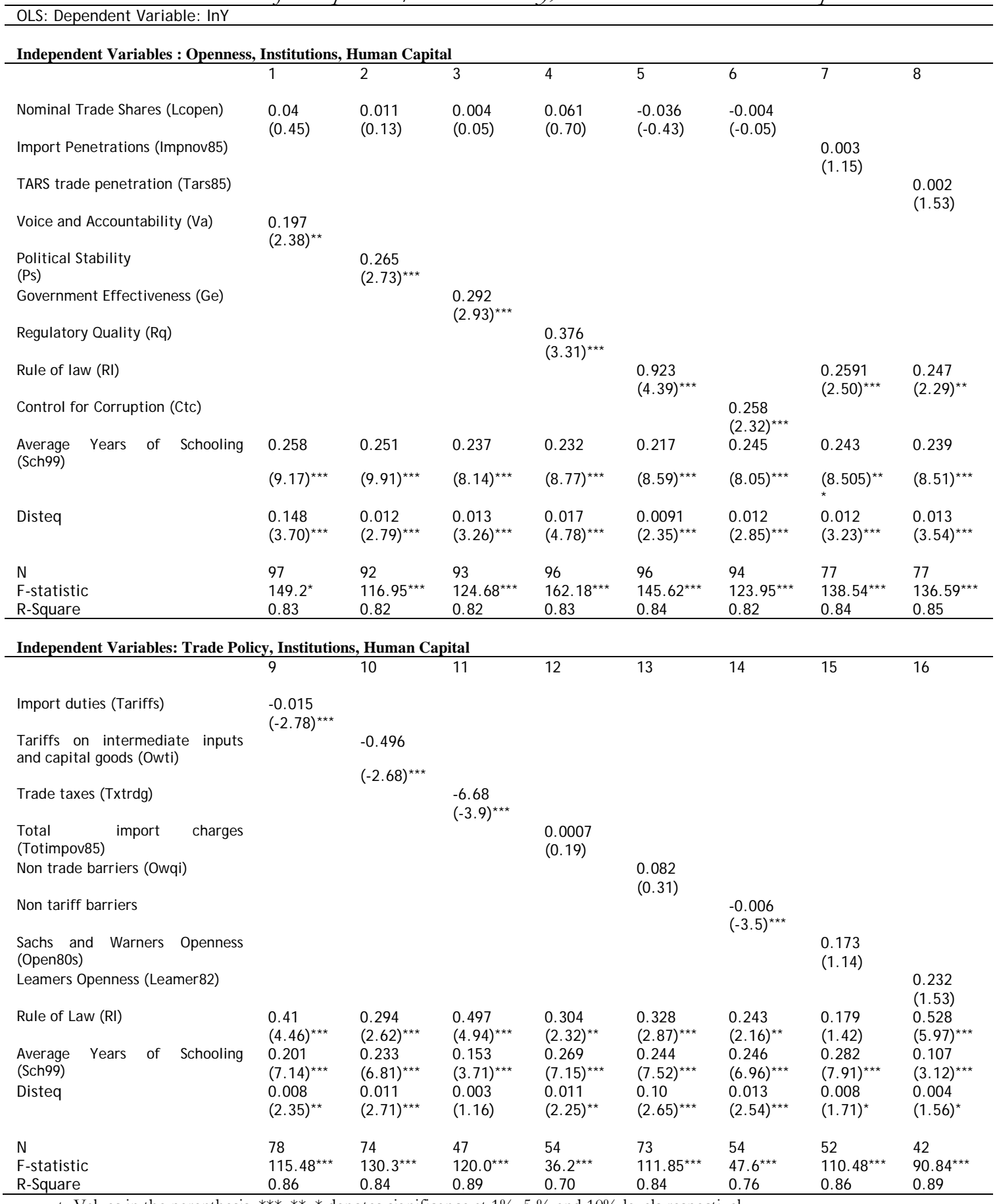

- $\quad \mathrm{t}$ - Values in the parenthesis. ***, **, * denotes significance at $1 \%, 5 \%$ and $10 \%$ levels respectively

\subsection{Our IV Analysis:}

Before proceeding to second stage regressions, it is necessary to examine how predicted values of openness/ trade policy, institutions and human capital relate to per-capita income in a linear framework to understand the forthcoming results better. Figure 1 provides graphical representations of linear relationship of per capita income $(\ln Y)$ with openness (Lcopen), trade policy (Txtrdg), rule of law (R/) and human capital (Sch99). The use of instrumental variables provides a clear picture of openness/ trade policy, institutions and human capital with regard to income. As expected Trade taxes, which were earlier found to be highly significant in OLS analysis, show a steeper slope showing higher responsiveness of income to a decline in trade taxes. Increase in general trade 
levels (openness) may also lead to a positive effect on income but the responsiveness is low. The difference of slope for Lcopen and Txtrdg can be attributed to the fact that the level of trade, as against a direct measure of trade policy, is capturing an omitted variable effect. There is also presence of strong and positive responsiveness in income for increases in human capital (Sch99) and institutions (R).

\section{Figure 1. Responsiveness of Income}
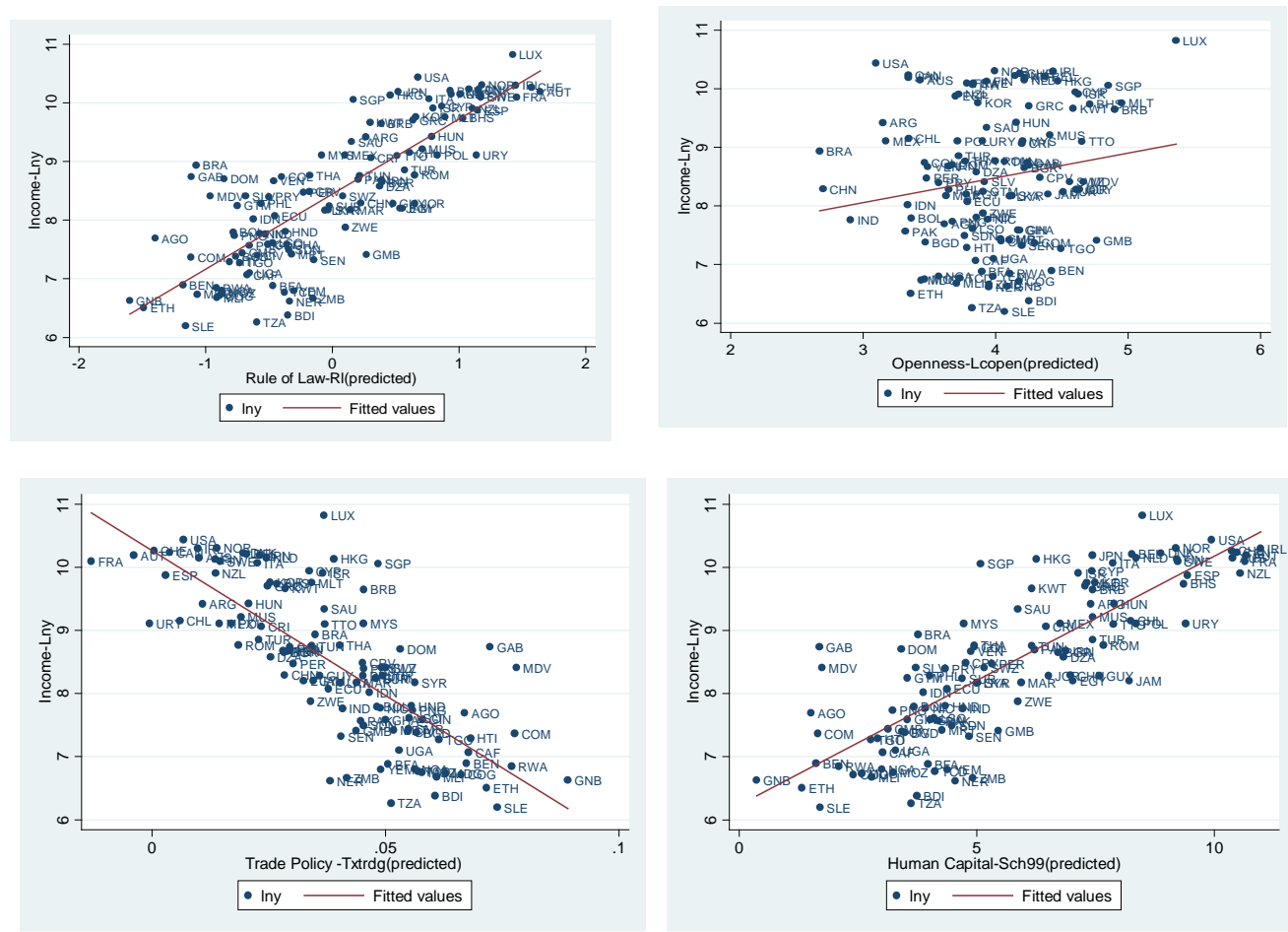

Moving on to the second stage regression analysis, Table 6 provides the results for percapita income equation for 11 openness/trade policy variables, 6 institutional proxies and human capital. In specification 2, which corresponds to the specification followed by Rodrik et al. (2004), the results are also similar to their study. Institutions clearly trump openness and trade policy; openness variables remained generally insignificant and if significant, enter eq. (1) with a wrong sign. Trade policy variables also remained insignificant under specification 2 with the exception of trade taxes, which are significant in at least 3 out of 6 cases.

However, for specification 1, where human capital also enters Eq. (1), the results present a different picture and challenge the position taken up by Rodrik et al. (2004). For specification 1, institutions are also insignificant. Compared to specification 2, the frequency of insignificance for openness reaches nearly 100 per cent in specifications 1 when human capital is considered in eq 1 , as well as having the wrong signs in most cases. The insignificance of openness proxies capturing the level of trade or movements in terms of trade is not surprising. These results are in accordance with the findings of Dollar and Kraay (2002) and Rodrik (1998), who suggest that the correlation of trade levels and growth performance is at best weak. The results of this paper reinforce this fact in a more comprehensive manner, as it provides additional specifications to the percapita income equation by including human capital. The inclusion of human capital improved the explanatory power of this model, as is evident from higher $R^{2}$ values. 
Table 6 Second stage regression results for

per-capita income under the complete set of specifications

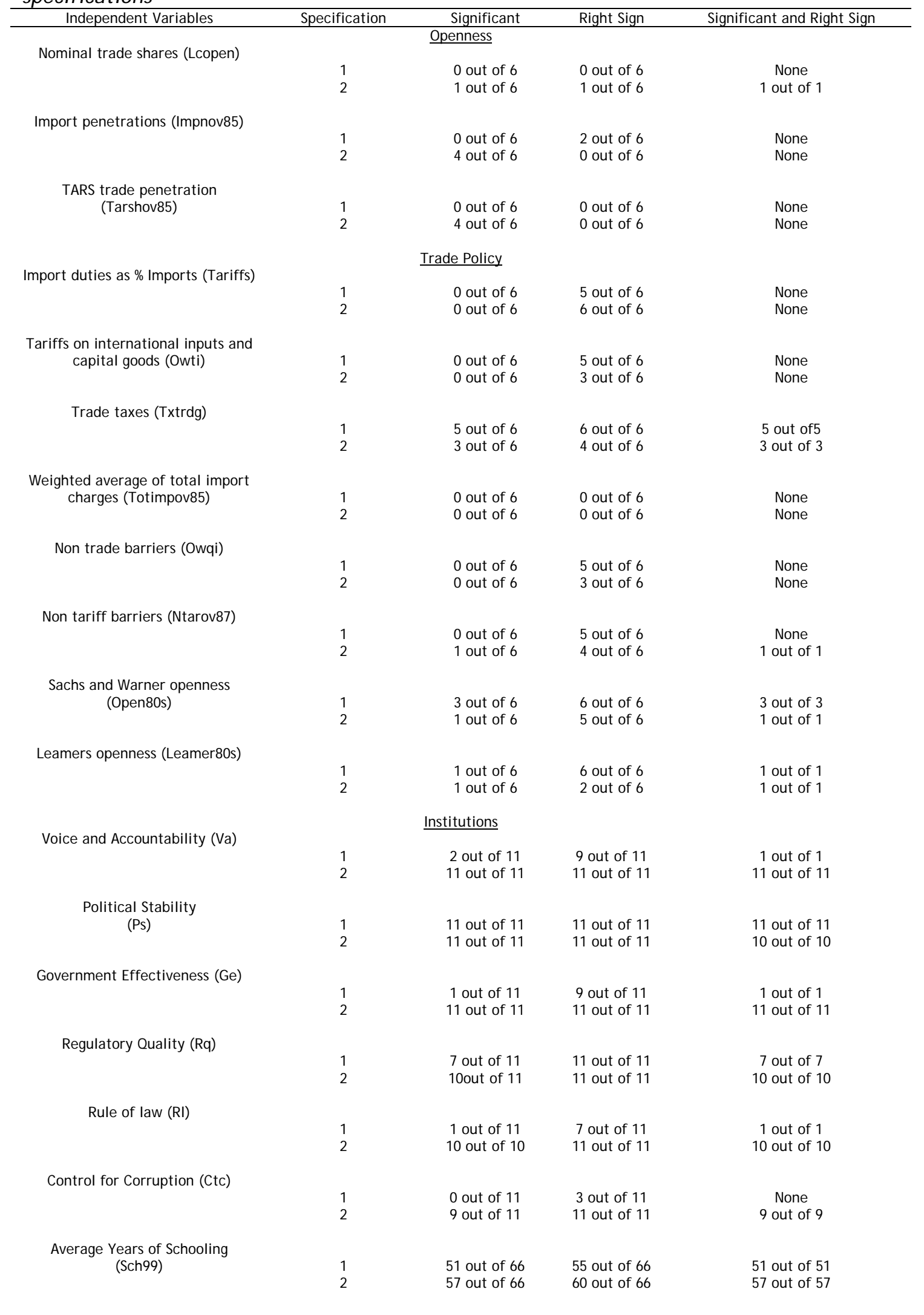

Standard errors corrected for as run Durbin-Wu-Hausman test (augmented regression test) for endogeneity (see Davidson and MacKinnon. 1993)

Table illustrates results for Eq. (2.1) under various general specifications. i.e., specification 1: openness or trade policy + Institutions + Sch99.

Specification 2: openness or trade policy + Institutions

- $\quad$ Note that specification 2 corresponds to the one adopted by Rodrik et al. (2004) for their growth equation 
As far as the trade policy variables are concerned, they are significant in some cases and the frequency of significance is much higher when compared to openness variables. Although trade policy indicators too can have wrong signs, ${ }^{3}$ unlike Rodrik et al. (2004) where in many instances openness variables show significance but carry wrong signs, trade policy variables, which carry incorrect signs, are generally insignificant. With the exception of Totimpov85, other trade policy variables always enter Eq. (1) with right signs whenever they are significant. Tariffs, Owti, Owqi and Ntarov87 also show wrong signs but in such instances, they have also been insignificant. In fact, Owqi, which has highest frequency of wrong signs next to Totimpov85, remains insignificant under all specifications and with any of the institutional combinations. By contrast, Txtrdg, which is the most significant trade policy variable, always enters the equation with a right (negative) sign showing that trade policy does matter and trade restrictiveness (export taxes) indeed lowers per-capita income or growth.

It is also important to understand why some trade policy variables have the wrong signs or are insignificant, when others have passed the test by emerging as significant contributors to economic success. With regard to the insignificance of import taxes, Totimpov85 one can suggest that their contribution depends upon the composition of goods imported. Here as mentioned in data definitions, we know that data for Totimpov85 and Ntarfov87 is available for developing countries only. Thus the explanation must come in a developing country context. For example, in a developing country the availability of technologically superior imported goods has positive effects on output and growth, but if imports are dominated by consumption goods, a reduction in import taxes may hamper growth potentials, and at a cost to the public exchequer. Rodrik (1998) supports this line of argument, as he found that changes in import taxes fail to influence growth in sub-Saharan African countries. According to Rodrik (1998), it is export taxes, which if lowered, contribute to growth. Thus in the context of a cross-sectional study, it is wiser to examine the impact of overall trade taxes (import and export) instead of looking at any one of them, in order to gain a general insight into the workings of trade taxes apropos economic activity. According to Rodriguez and Rodrik (2000), overall trade taxes capture trade restrictiveness in a more complete manner than other trade policy proxies do, as it is comprised of both import and export taxes. Trade taxes (export plus import taxes) include developed and developing countries in its sample and thus the results can be comparable to the larger sample of Lcopen.

Not surprisingly, Txtrg (overall trade taxes) comes out to be the most important trade policy variable since it shows significance in many instances in all three specifications (see Table 6). To be exact, Txtrdg is significant in five out of six cases in specification 1, and three out of six cases in specification 2 . Note that trade taxes are most significant in specification 1 where human capital enters the per capita equation. In comparison, under the same specification, the institutional proxies generally enter eq. (1) as insignificant. This is again an important result if compared with the results obtained by Rodrik et al. (2004), where openness was generally insignificant and institutions (rule of law) have largely been highly significant at one per cent level of significance

\subsubsection{A Comparison of Trade Taxes (Txtrdg) with Trade Shares (Lcopen):}

It is evident from the overall summary of the results presented in table 6 that out come based measures of trade barriers perform poorly in the regressions when compared to incidence based measures. To further validate this observation, a detailed analysis is

3 This occurs when import protection increases per-capita income. 
presented in this section where performance of conventional measure of openness is analysed against trade taxes under two general specifications 1 and 2 .

Table 7 shows the results for Lcopen (openness) where it enters the per capita income equation with all six proxies of institutions one by one with and without human capital (sch99) respectively. Out of 12 different cases, Lcopen is significant in only two of them and it carries a wrong sign in at least one of these two cases. In column 12, where openness enters with the wrong sign, the IV equation fails to pass over identification test as shown by the low $\mathrm{P}$ value highlighted in grey. In contrast, column 8 shows the only case where openness is significant and with the right sign, while the IV model also passes both over-identification test as well as relevance test as shown by high $\mathrm{P}$ values and minimal 2SLS bias respectively. Despite this, both columns 12 and 8 represent model specification 2, where $S \operatorname{ch} 99$ is not present in the equation. In presence of $S \operatorname{ch99}$, Lcopen is always insignificant and institutions are insignificant for 4 out of 6 cases.

The very presence of human capital in combination with Lcopen and institutional proxies actually weakens the over all statistical validity of the model. For all instances when human capital has entered the equation 1 in table 7 , either the model fails overidentification test or it suffers from large 2SLS bias which favours OLS over IV. The poor results may indicate the problem of endogeneity which may go from Lcopen to human capital because of omitted variable bias or from institutions to human capital that has not been captured by the instruments. Employing a direct measure of trade policy may minimise the risk of omitted variable bias and at least the statistical validity of IV analysis would be more robust. A detailed analysis of trade taxes under the general specifications 1 and 2 suggests that for 12 different cases presented in 12 different columns of table 8 , there is not a single instance when the IV analysis had suffered from the problem of endogeneity. Evidently, trade taxes improve the statistical validity of IV analysis in comparison to conventional measure of openness. They are also significant in most cases and always enter the per capita income equation with the right sign. To really compare openness (Lcopen) and trade taxes (Txtrdg), similar samples have to be employed. Data for Lcopen is available for 170 countries and for Txtrdg the data is only available for 54 countries. Sample details of all countries for both variables are available at the end of the paper. In order to compare results of Lcopen and Txtrdg, IV analysis on Lcopen is carried out for the reduced sample of countries corresponding to the countries for which data is available for Txtrdg. The results are presented in columns 13 to 18 of table 7 . Reduced sample IV analysis for Lcopen is carried out for general model specification 1 only, where Sch99 is regressed alongside openness and institutions. The results do not change in favour of openness.

For a reduced sample of countries also, Lcopen is insignificant, and the IV model either fails over-identification tests or suffers from large 2SLS bias. One can infer from these results that if human capital is included along with Lcopen, OLS gives more reliable results. The one instance of significance of Lcopen with the right sign in column 8 (table 7) corresponds to the large sample of Rodrik et al (2004) where instead of settler mortality, the regressors are instrumented by Engfrac and Eurfrac and always fail over identification tests. Unlike their results, Lcopen does not fail over identification test when it is significant. This also means that insignificance and wrong signs of Lcopen were more of an outcome of endogeneity in the analysis rather than signalling towards the validity of the results for Rodrik et al (2004). 
Table 7 Second stage regression results for Lcopen and institutions

\begin{tabular}{|c|c|c|c|c|c|c|c|c|c|c|c|c|c|c|c|c|c|c|}
\hline \multicolumn{19}{|c|}{ Dependent Variable: $\ln Y$} \\
\hline \multicolumn{13}{|c|}{$\begin{array}{l}\text { Complete sample of Lcopen } \\
\qquad(\mathrm{n}=170)\end{array}$} & \multicolumn{6}{|c|}{$\begin{array}{l}\text { Reduced Sample of Lcopen if } \\
\text { (Dum Txtrdg, } n=54 \text { ) }\end{array}$} \\
\hline $\begin{array}{l}\text { Independent } \\
\text { Variables }\end{array}$ & 1 & 2 & 3 & 4 & 5 & 6 & 7 & 8 & 9 & 10 & 11 & 12 & 13 & 14 & 15 & 16 & 17 & 18 \\
\hline \multirow{2}{*}{$\begin{array}{l}\text { Nominal Trade Shares } \\
\text { (Lcopen) }\end{array}$} & 0.027 & 0.036 & -0.307 & -0.126 & -0.75 & -0.236 & 0.104 & 0.389 & -0.021 & -0.237 & 1.189 & -0.406 & 0.077 & -0.71 & -0.07 & 0.071 & -0.2 & 0.246 \\
\hline & $(0.23)$ & $(0.20)$ & $(-0.69)$ & $(-0.56)$ & $(-0.7)$ & $(-1.14)$ & $(0.84)$ & $(2.20)^{* *}$ & $(-0.10)$ & $(-1.02)$ & $(0.88)$ & $(-1.8)^{*}$ & $(0.53)$ & $(-0.8)$ & $(-0.5)$ & $(0.39)$ & $(-1.1)$ & $(0.82)$ \\
\hline \multirow{2}{*}{$\begin{array}{l}\text { Voice and Accountability } \\
\text { (Va) }\end{array}$} & 0.427 & 1.070 & & & & & & & & & & & 0.206 & & & & & \\
\hline & $(1.79)^{*}$ & $(8.02)^{* * 1 *}$ & & & & & & & & & & & $(0.68)$ & & & & & \\
\hline \multirow{2}{*}{$\begin{array}{l}\text { Political Stability } \\
\text { (Ps) }\end{array}$} & & & 2.37 & 1.788 & & & & & & & & & & 2.917 & & & & \\
\hline & & & $(1.51)$ & $(5.27)^{*+* *}$ & & & & & & & & & & $(0.97)$ & & & & \\
\hline \multirow{2}{*}{$\begin{array}{c}\text { Government } \\
\text { Effectiveness (Ge) }\end{array}$} & & & & & 3.54 & 1.519 & & & & & & & & & 0.666 & & & \\
\hline & & & & & $(1.08)$ & $(6.08)^{* * *}$ & & & & & & & & & $(2.2)^{* *}$ & & & \\
\hline \multirow[t]{2}{*}{ Regulatory Quality (Rq) } & & & & & & & 1.003 & 1.486 & & & & & & & & 1.459 & & \\
\hline & & & & & & & $(2.69)^{* * * *}$ & $(7.03)^{* * 1 *}$ & & & & & & & & $(1.8)^{* 2 * *}$ & & \\
\hline \multirow[t]{2}{*}{ Rule of law (RI) } & & & & & & & & & 0.333 & 1.802 & & & & & & & 1.22 & \\
\hline & & & & & & & & & $(0.63)$ & $(4.85)^{* * * k}$ & & & & & & & $(2.0)^{* *}$ & \\
\hline \multirow{2}{*}{$\begin{array}{l}\text { Control for Corruption } \\
\text { (Ctc) }\end{array}$} & & & & & & & & & & & -2.81 & 1.488 & & & & & & -0.50 \\
\hline & & & & & & & & & & & $(-0.85)$ & $(5.57)^{* * *}$ & & & & & & $(-0.73)$ \\
\hline \multirow{2}{*}{$\begin{array}{l}\text { Average Years of } \\
\text { Schooling (Sch99) }\end{array}$} & 0.272 & & -0.194 & & -0.528 & & 0.154 & & 0.293 & & 0.532 & & 0.321 & -0.24 & 0.131 & 0.061 & 0.041 & 0.543 \\
\hline & $(3.43)^{* 1+k}$ & & $(-0.39)$ & & $(-0.4)$ & & $(1.69)^{*}$ & & $(2.18)^{* *}$ & & $(0.85)$ & & $(3.1)^{*+* k}$ & $(-0.3)$ & (1.48) & $(0.31)$ & $(0.21)$ & $(2.5)^{* * *}$ \\
\hline \multirow[t]{2}{*}{ Disteq } & 0.004 & 0.012 & -0.015 & -0.009 & -0.011 & 0.001 & 0.014 & 0.022 & 0.002 & -0.016 & 1.077 & -0.0004 & 0.004 & -0.04 & 0.004 & 0.011 & -0.01 & 0.009 \\
\hline & $(0.62)$ & $(2.34)^{* *}$ & $(-0.65)$ & $(-0.61)$ & $(-0.4)$ & $(0.18)$ & $(2.43)^{* k}$ & $(3.97)^{* \text { *ak }}$ & $(0.32)$ & $(-1.16)$ & $(1.30)$ & $(-0.04)$ & $(0.52)$ & $(-0.8)$ & $(0.69)$ & (1.58) & $(-0.88)$ & $(0.95)$ \\
\hline N & 88 & 130 & 84 & 119 & 85 & 120 & 87 & 127 & 87 & 127 & 86 & 122 & 45 & 43 & 43 & 45 & 45 & 44 \\
\hline F-statistic & $76.59 * * *$ & $78.99 * *$ & $8.98^{* * 2 *}$ & $24.95^{* * *}$ & 5.55 & $41.26^{* * *}$ & $63.01^{* * *}$ & $80.21^{* * *}$ & $89.54^{* * * *}$ & $35.51^{* * *}$ & 6.27 *** & $42.56^{* * *}$ & $37.7^{* 2 * k}$ & 4.71 & $38.2^{* * * k}$ & $23.95^{* * *}$ & $36.71^{* *}$ & $21.7^{* * *}$ \\
\hline R-Square & 0.80 & 0.53 & 0.57 & 0.08 & 0.05 & 0.44 & 0.76 & 0.51 & 0.84 & 0.33 & 0.85 & 0.457 & 0.816 & 0.39 & 0.83 & 0.70 & 0.81 & 0.69 \\
\hline Maximal 2SLS Bias & 0.009 & 0.000 & 0.746 & 0.005 & 0.886 & 0.000 & 0.013 & 0.000 & 0.393 & 0.002 & 0.80 & 0.000 & 0.009 & 0.870 & 0.198 & 0.362 & 0.413 & 0.337 \\
\hline Sargan (P) & $0.017^{* *}$ & 0.27 & 0.748 & 0.67 & 0.928 & 0.24 & 0.24 & 0.405 & $0.001^{* * *}$ & 0.128 & 0.88 & $0.021^{* *}$ & $0.01^{* * *}$ & 0.777 & $0.08^{* * * *}$ & 0.222 & 0.059 & 0.067 \\
\hline
\end{tabular}

$\mathrm{t}$ - Values in the parenthesis. ${ }^{* * *}, * * *$ denotes significance at $1 \%, 5 \%$ and $10 \%$ levels respectively, Standard errors corrected for as run Durbin-Wu-Hausman test (augmented regression test) for
endogeneity (see Davidson and MacKinnon. 1993) 
Table 8 Second stage regression results for Txtrdg and institutions

\begin{tabular}{|c|c|c|c|c|c|c|c|c|c|c|c|c|}
\hline \multicolumn{13}{|c|}{ Dependent Variable: Log of Per-Capita Income } \\
\hline $\begin{array}{l}\text { Independent } \\
\text { Variables }\end{array}$ & 19 & 20 & 21 & 22 & 23 & 25 & 25 & 26 & 27 & 28 & 29 & 30 \\
\hline \multirow[t]{2}{*}{ Trade Taxes (Txtrdg) } & -18.14 & 3.293 & -23.21 & -23.248 & -16.67 & -9.514 & -12.261 & 2.38 & -19.408 & -22.135 & -26.903 & -21.909 \\
\hline & $(-2.1)^{* *}$ & $(0.21)$ & $(-1.69)^{*}$ & $(-1.93)^{*}$ & $(-2.13)^{* *}$ & $(-0.62)$ & $(-1.24)$ & (0.18) & $(-2.16)^{* *}$ & $(-2.10)^{* *}$ & $(-1.77)^{*}$ & $(-2.20)^{* *}$ \\
\hline \multirow[t]{2}{*}{ Voice and Accountability (Va) } & 0.258 & 1.11 & & & & & & & & & & \\
\hline & $(0.65)$ & $(2.72)^{* * *}$ & & & & & & & & & & \\
\hline \multirow{2}{*}{$\begin{array}{l}\text { Political Stability } \\
\text { (Ps) }\end{array}$} & & & 1.160 & 1.337 & & & & & & & & \\
\hline & & & $(1.89)^{*}$ & $(3.16)^{* * * *}$ & & & & & & & & \\
\hline \multirow[t]{2}{*}{ Government Effectiveness (Ge) } & & & & & 0.597 & 1.188 & & & & & & \\
\hline & & & & & $(2.18)^{* *}$ & $(3.53)^{* * * *}$ & & & & & & \\
\hline \multirow[t]{2}{*}{ Regulatory Quality (Rq) } & & & & & & & 1.088 & 1.62 & & & & \\
\hline & & & & & & & (1.48) & $(2.96)^{* * *}$ & & & & \\
\hline \multirow[t]{2}{*}{ Rule of law (RI) } & & & & & & & & & 0.751 & 1.281 & & \\
\hline & & & & & & & & & $(2.06)^{* *}$ & $(2.68)^{* * *}$ & & \\
\hline \multirow[t]{2}{*}{ Control for Corruption (Ctc) } & & & & & & & & & & & 0.575 & 0.882 \\
\hline & & & & & & & & & & & $(1.24)$ & $(3.29)^{* * *}$ \\
\hline \multirow[t]{2}{*}{ Average Years of Schooling (Sch99) } & 0.1707 & & -0.056 & & 0.035 & & 0.050 & & 0.018 & & -0.022 & \\
\hline & (1.25) & & $(-0.34)$ & & $(0.33)$ & & $(0.36)$ & & $(0.17)$ & & $(-0.10)$ & \\
\hline \multirow[t]{2}{*}{ Disteq } & 0.004 & 0.008 & -0.011 & -0.017 & 0.005 & -0.007 & 0.010 & 0.019 & -0.0015 & -0.021 & 0.004 & -0.007 \\
\hline & $(0.51)$ & $(0.94)$ & $(-0.65)$ & $(-1.07)$ & $(0.75)$ & $(-0.65)$ & (1.49) & $(2.23)^{* *}$ & $(-0.16)$ & $(-1.19)$ & $(0.36)$ & $(-0.57)$ \\
\hline N & 45 & 52 & 43 & 50 & 43 & 50 & 45 & 52 & 45 & 52 & 45 & 51 \\
\hline F-statistic & $34.69^{* * *}$ & $35.22^{* * *}$ & $19.50^{* * * *}$ & $12.12^{* * * *}$ & $32.23^{* 2 * k}$ & $22.64 * * *$ & $63.76^{\text {*t*k }}$ & $36.79^{* * * *}$ & $53.34^{* * 2 *}$ & $18.49^{* * * *}$ & $23.68^{* * * *}$ & $24.08^{* * *}$ \\
\hline R-Square & 0.76 & 0.66 & 0.49 & 0.25 & 0.79 & 0.61 & 0.79 & 0.61 & 0.80 & 0.49 & 0.61 & 0.61 \\
\hline Maximal 2SLS Bias & 0.20 & 0.13 & 0.46 & 0.08 & 0.13 & 0.06 & 0.52 & 0.198 & 0.18 & 0.074 & 0.48 & 0.043 \\
\hline Sargan $(P)$ & 0.143 & 0.311 & 0.97 & 0.507 & 0.24 & 0.244 & 0.14 & 0.361 & 0.33 & 0.257 & 0.36 & 0.143 \\
\hline
\end{tabular}

- $\mathrm{t}$ - Values in the parenthesis. ***, **, * denotes significance at 1\%, $5 \%$ and $10 \%$ levels respectively, Standard errors corrected for as run Durbin-Wu-Hausman test (augmented regression test) for endogeneity (see Davidson and MacKinnon. 1993), Please also refer to Table 2.11, where give results for Eq. (2.5); Txtrdg, when compared with Lcopen is highly significant. 


\subsubsection{Significance of Trade Policy}

This paper also includes more specific proxies of trade restrictiveness (tariffs and non-tariff barriers), in an attempt to identify the optimal trade policy tools for policymakers. In Table 6, Owti (tariffs on intermediate inputs and capital goods) and Owqi (non-tariff barriers on intermediate inputs and capital goods) have been insignificant under all specifications of the per-capita income equation and with any of the institutional combinations. Though Ntarfov (overall non-tariff barriers) shows significance for specification 2 when it enters the equation with rule of law, it does not say much about the role of non-tariff barriers (NTBs), as Ntarfov remains insignificant for the other five institutional proxies under the same specification. The insignificance of TB and NTBs does come as a surprise. Dollar and Kraay (2002) share this scepticism over the relevance of these measures of trade policy with the likes of Rodriguez and Rodrik (2000) and Frankel and Romer (1999). Perhaps this is why trade policy variables are virtually absent in the recent empirical debate over trade and institutions. For example, Frankel and Romer (1999), Acemoglu, Johnson and Robinson (2001), Alcala and Ciccone (2002), Dollar and Kraay (2002) and Rodrik et al. (2004) all tried to find partial effects of trade and institutions on per-capita income or its growth by taking into account only the general openness indicator (trade over GDP ratio).

Many studies tried to capture the effects of trade policy on economic development: Sachs and Warner (1995), Edwards (1998) and Greenaway, Morgan and Wright (2002) are among the prominent studies that employed direct proxies of trade policies. They confirm that the countries with policy-induced barriers to international trade grow at a slower pace. Notwithstanding the important role of these studies in providing useful insights into the 'trade and growth' debate, they have two shortcomings. First, in light of recent evidence provided by Rodrik et al. (2004), and Dollar and Kraay (2002), their studies are likely to suffer from misspecification bias, as their growth equations do not account for institutions. Second, they assumed that trade policy is purely exogenous.

Wood (2004), commenting on the 'trade and growth' debate not only emphasised that a more convincing basis for trade policy recommendations could only be provided if trade policy variables are included in the regressions. He also pointed out that any such attempt should consider trade policy as an endogenous concept as no trade policy recommendations can be given without taking second best effects into account. This is because trade policies crucially depend on the functioning of domestic markets of any particular country, and if these are imperfect, second best considerations enter the picture. The analysis here addresses the endogeneity of trade policy variables by regressing them on a set of instruments. Although the instruments remain general in nature, they do capture certain country specific characteristics. Moreover, as the per-capita, income equation has institutional proxies and human capital along with trade policy variables, the analysis goes a step further from previous cross-sectional studies, which attempted to gauge the effects of trade policy on economic development.

Although some of the present trade policy variables are insignificant, certain trade proxies do appear that show that trade policy matters in determining economic prosperity when examined alongside human capital and institutional quality variables. Overall, the results suggest that the general openness variables fail to explain per-capita income differences 
compared to direct proxies of the trade policy stance. For example, lcopen, Impnov and Tarshov show insignificance in all specifications, suggesting their weak relationship with income. By contrast, the results suggest that decreases in overall trade taxes are associated with strong improvements in economic performance.

\section{Conclusions}

Do institutions dominate international economic participation in explaining differences in per-capita income across countries? It must be remembered that it is impossible to overemphasise the importance of institutions in determining the economic development of a country. We find in line with Rodrik et al (2004) that institutions do matter but unlike their study we also find that they are not always the most important variable to explain economic growth. Basu (2008) also finds that although institutions are important, but once a richer development quality index to capture well-being and a richer institutional quality index is employed, institutional contributions to well-being depend on the particular type of economic policy mix being followed, as well as the geographical context. Bhupatiraju and Verspagen (2013), also using different measures of prosperity (including growth instead of per-capita income levels) and a richer set of institutional data as well as geographical definitions, find that institutions may matter less than expected. There tends to be a geographical clustering of the type of institutions, implying that neighbouring countries have similar institutions. Using broader development definitions, instead of per-capita income, differences in attainment between countries relate also to geography (in a broader sense than simply distance from the equator) and trade openness (not trade policy). Neither of these two papers employs trade policy instruments, as in our analysis, utilising instead conventional trade-GDP (openness) ratios.

Furthermore, we find that developing human capital is as important as superior institutional functioning for economic wellbeing, similar to Glaeser et al. (2004a and 2004b). Indeed the accumulation of human capital stocks via increased education might lead to improved institutional functioning, and the successful utilisation of policies like trade liberalisation. Baliamoune-Lutz and Ndikumana (2007), for example, find that the success of trade liberalisation in promoting growth in sub-Saharan Africa is hindered by the absence of good institutions.

With regard to the role of international integration versus institutions, the finding here is that openness counts for little per se in explaining income differences across countries. This is because it is an outcome and not a cause. Trade policies, and liberalisation, on the other hand, are significant in explaining cross-country per-capita income variation. With regard to trade policies, the data show that the overall policy stance, particularly those associated with black market premia in foreign exchange markets and export taxes, are most important. The presence of these two phenomena relate closely to poor institutional performance. Tariffs and quotas on imports, however, are of secondary importance, indicating that they are less growth retarding. Our findings regarding the importance of sound trade policies also need to be contextualised in the light of the recent analysis by Rodrik (2015) who argues that openness and trade liberalisation can contribute to premature deindustrialization, at lower levels of per-capita income compared to developed countries, especially in Africa and Latin America. Liberalisation and free trade leads to developing countries which do not already 
have a comparative advantage in manufacturing importing deindustrialization from advanced developed economies, such as the USA or UK.

\section{References:}

Acemoglu, D., S. Johnson and J. Robinson (2004) 'Institutions as the Fundamental Cause of LongRun Growth,' NBER Working Papers 10481, National Bureau of Economic Research, Inc.

Acemoglu, D., S. Johnson and J. A. Robinson (2001) 'The Colonial Origins of Comparative Development: An Empirical Investigation', American Economic Review 91(5): 1369-1401, http://emlab.berkeley.edu/users/chad/e236c_f04/ajr2001.pdf

Alcala, F. and A. Ciccone (2004) 'Trade and Productivity', CEPR Discussion Paper No. 3095.

Anderson, T. W., \& Rubin, H. (1956) Statistical inference in factor analysis. Proceedings of the Third Berkeley Symposium on Mathematical Statistics and Probability. Berkeley: The University of California Press

http://projecteuclid.org/DPubS/Repository/1.0/Disseminate?handle=euclid.bsmsp/1200511860\& view $=$ body\&content-type $=$ pdf_1

Anderson, T. W., \& Rubin, H. (1949). 'Estimation of the Parameters of a Single Equation in a Complete System of Stochastic Equations,' Annals of Mathematical Statistics, 20: 46-63

Baliamoune-Lutz, M. and L. Ndikumana (2007) 'The Growth Effects of Openness to Trade and the Role of Institutions: New Evidence from African Countries', Working Paper 2007-05, Department of Economics, University of Massachusetts, Amherst.

Barro, R. J. and J. W. Lee (2001) 'International Data on Educational Attainment: Updates and Implications', Oxford Economic Papers, 53(3): 541-63.

Barro, R. J. and J. W. Lee (1996) 'International Measures of Schooling Years and Schooling Quality', American Economic Review, 86(2): 218-23

Barro, R. J. and J. W. Lee (1993) 'International Comparisons of Educational Attainment', Journal of Monetary Economics, 32(3): 363-394.

Basu, S.R. (2008) 'A New Way to Link Development to Institutions, Policies and Geography', Policy Issues in International Trade and Commodities Study Series No. 37, UNCTAD.

Baum, C. F., M. E. Schaffer and S. Stillman (2003) 'Instrumental Variables and GMM: Estimation and Testing' The Statat Journal, 3(1): 1-31

Bhupatiraju, S. and B. Verspagen (2013) 'Economic DevDevelopment, Growth, Institutions and Geography, UNU-MERIT Working Paper No. 2013-56.

Cragg, J. G. and S. G. Donald (1993) 'Testing Indentifiability and Specification in Instrumental Variable Models,' Econometric Theory, 9: 222-240.

Cruz, L.M. and M. J. Moreira (2005) 'On the Validity of Econometric Techniques with Weak Instruments: Inference on Returns to Education Using Compulsory School Attendance Laws' Journal of Human Resources, 10 (2): 393-410.

Dollar, D. (1992) 'Outward-Oriented Developing Economies Really Do Grow More Rabidly: Evidence from 95 LDCs, 1976-85,' Economic Development and Cultural Change, 523-544

Dollar, D. and A. Kraay (2004) 'Trade, Growth, and Poverty', Economic Journal 114: F22-F49.

Dollar, D. and A. Kraay (2003) 'Institutions, Trade and Growth', Journal of Monetary Economics 50(1): $133-62$.

Dollar, D. and A. Kraay (2002) 'Growth Is Good for the Poor,' Journal of Economic Growth, 7(3): 195225.

Easterly, W. and R. Levine (2003) 'Tropics, Germs and Crops: How Endowments Influence Economic Development', Journal of Monetary Economics 50(1): 3-39. 
Edwards, S. (1992) 'Trade Oreintation, Distortions, and Growth in Developing Countries,' Journal of Development Economics, 39 (1): 31-57.

Edwards, S. (1998) 'Openness, Productivity and Growth: What Do We Really Know?', Economic Journal 108: 383-98.

Frankel, J. and D. Romer (1999) 'Does Trade Cause Growth?', American Economic Review 89(3): 37999.

Glaeser, E.L., R. La Porta,, F. Lopez-de-Silanes and A. Shleifer (2004a) 'Do Institutions cause Growth', Journal of Economic Growth 9(3): 271-303.

Glaeser, E.L., R. La Porta,, F. Lopez-de-Silanes, and A. Shleifer (2004b) 'Explaining Growth: Institutions, Human Capital, and Leaders', PD: Preliminary Draft, http://www.brook.edu/es/commentary/journals/bpea macro/papers/20040325 glaeser.pdf.

Greenaway D., W. Morgan and P. Wright (2001) 'Trade Liberalisation and Growth in Developing Countries', Journal of Development Economics 67: 229-34.

Hahn, J. and Hausman, J. (2002) 'A new specification test for the validity of instrumental variables', Econometrica, 70(1): 163-189

Hall, R.E, and C. Jones (1999) 'Why do Some Countries Produce So Much More Output per Worker than Others?', Quarterly Journal of Economics 114: 83-116.

Kaufman, D., A. Kraay and Z. Lobaton (2003) 'Governance Matters III: Governance Indicators for 1996-2002', Policy Research Working Paper 2772, Washington DC: World Bank, http://www.worldbank.org/wbi/ governance/pdf/govmatters3.pdf.

Leamer, E. (1988) 'Measures of Openness' in (R. Baldwin, ed.) Trade Policy and Empirical Analysis, Chicago: University of Chicago Press

Pritchett, L. (2000) 'Understanding Patterns of Economic Growth: Searching for Hills among Plateaus, Mountains, and Plains,' World Bank Economic Review, 14: 221-250.

Pritchett, L. (1996) 'Measuring outward orientation in LDCs: Can it be done?', Journal of Development Economics, 49(2): 307-335.

Rodriguez, F. and D. Rodrik (2000) 'Trade Policy and Economic Growth: A Skeptic's Guide to the Cross-National Evidence', NBER Macroeconomics Annual 2000, 15: 261.

Rodrik, D. (2015) 'Premature Deindustrialization', IAS School of Social Science Economics Working Paper No. 107.

Rodrik, D. (2004) 'Globalization and growth -- looking in the wrong places,' Journal of Policy Modeling, Elsevier, 26(4): 513-517.

Rodrik, D. (1998) 'Trade Policy and Economic Performance in Sub-Saharan Africa,' NBER Working Paper 6562 .

Rodrik, D., A. Subramanian and F. Trebbi (2004) 'Institutions Rule: The Primacy of Institutions Over Geography and Integration in Economic Development', Journal of Economic Growth 9(2): 131-65.

Rose, A. (2002) 'Do WTO Members Have a More Liberal Trade Policy?', NBER Working Paper 9347.

Sachs, J.D. and A. Warner (1995) 'Economic Reform and Process of Global Integration', Brookings Papers on Economic Activity 1: 1-118.

Staiger, D and H. J. Stock, (1997) 'Instrumental Variables Regression with Weak Instruments', Econometrica, 65(3): 557-586.

Stock. J. H. \& M. Yogo (2004) "Testing for Weak Instruments in Linear IV Regression," NBER Technical Working Papers 0284, National Bureau of Economic Research, Inc. 
Wood, C. (2004), 'The Empirics of Trade and Growth: Where are the Policy Recommendations,' __ http://www.ires.ucl.ac.be/DP/IRES DP/2004-13.pdf 


\begin{tabular}{|c|c|c|c|}
\hline Angola & Algeria & Kuwait & Qatar \\
\hline Albania & Ecuador & Lao PDR & Romania \\
\hline Argentina & Egypt, Arab Rep. & Lebanon & Russian Federation \\
\hline Armenia & Eritrea & St. Lucia & Rwanda \\
\hline Antigua and Barbuda & Spain & Sri Lanka & Saudi Arabia \\
\hline Australia & Estonia & Lesotho & Sudan \\
\hline Austria & Ethiopia & Lithuania & Senegal \\
\hline Azerbaij an & Finland & Luxembourg & Singapore \\
\hline Burundi & Fiji & Latvia & Sierra Leone \\
\hline Belgium & France & Macao, China & El Salvador \\
\hline Benin & Micronesia, Fed. Sts. & Morocco & Sao Tome and Principe \\
\hline Burkina Faso & Gabon & Moldova & Suriname \\
\hline Bangladesh & United Kingdom & Madagascar & Slovak Republic \\
\hline Bulgaria & Georgia & Mexico & Slovenia \\
\hline Bahrain & Ghana & Macedonia, FYR & Sweden \\
\hline Bahamas, The & Guinea & Mali & Swaziland \\
\hline Belarus & Gambia, The & Malta & Seychelles \\
\hline Belize & Guinea-Bissau & Myanmar & Syrian Arab Republic \\
\hline Bermuda & Equatorial Guinea & Mongolia & Chad \\
\hline Bolivia & Greece & Northern Mariana Islands & Togo \\
\hline Brazil & Grenada & Mozambique & Thailand \\
\hline Barbados & Guatemala & Mauritania & Tajikistan \\
\hline Bhutan & Guyana & Mauritius & Turkmenistan \\
\hline Botswana & Hong Kong, China & Malawi & Trinidad and Tobago \\
\hline Central African Republic & Honduras & Malaysia & Tunisia \\
\hline Canada & Croatia & Namibia & Turkey \\
\hline Switzerland & Haiti & Niger & Taiwan \\
\hline Chile & Hungary & Nigeria & Tanzania \\
\hline China & Indonesia & Nicaragua & Uganda \\
\hline Cote d'Ivoire & India & Netherlands & Ukraine \\
\hline Cameroon & Ireland & Norway & Uruguay \\
\hline Congo, Rep. & Iran, Islamic Rep. & Nepal & United States \\
\hline Colombia & Iceland & New Zealand & Uzbekistan \\
\hline Comoros & Israel & Oman & St. Vincent and the \\
\hline Cape Verde & Italy & Pakistan & Grenadines \\
\hline Costa Rica & Jamaica & Panama & Venezuela, RB \\
\hline Cuba & J ordan & Peru & Virgin Islands (U.S.) \\
\hline Cyprus & Japan & Philippines & Vietnam \\
\hline Czech Republic & Kazakhstan & Papua New Guinea & Yemen, Rep. \\
\hline Germany & Kenya & Poland & Yugoslavia, Fed. Rep. \\
\hline Djibouti & Kyrgyz Republic & Puerto Rico & South Africa \\
\hline Dominica & Cambodia & Portugal & Congo, Dem. Rep. \\
\hline Denmark & St. Kitts and Nevis & Paraguay & Zambia \\
\hline Dominican Repu & Korea, Rep. & & Zimbabwe \\
\hline
\end{tabular}


List of Countries for Trade Taxes/ Trade, 1982: Txtrdg Australia

Austria

Belgium

Bolivia

Brazil

Canada

Chile

Cote d'Ivoire

Cameroon

Congo, Rep.

Colombia

Denmark

Dominican Republic

Spain

Ethiopia

Finland

France

Gabon

United Kingdom

Greece

Honduras

Indonesia

India

Ireland

Iran, Islamic Rep.

Italy

Jamaica

Kuwait

Sri Lanka

Lesotho

Morocco

Mexico

Macedonia, FYR

Mauritania

Malaysia

Niger

Nicaragua

Netherlands

Norway

Oman

Pakistan

Paraguay

Rwanda

Singapore

Sweden

Thailand

Trinidad and Tobago

Tunisia

Turkey

Tanzania

United States

Venezuela, RB

Yugoslavia, Fed. Rep.

South Africa

Congo, Dem. Rep.

Zimbabwe 